\title{
Três Forquilhas Valley in Southern Brazil - evidence for the uplift of the volcanic plateau
}

\author{
Paul Edwin POTTER ${ }^{1}$, Roberto VERDUM² ${ }^{2}$ Michael HOLZ ${ }^{3}$, Débora Pinto MARTINS ${ }^{4}$ \& Nelson LISBOA ${ }^{5}$
}

1.Geology Department, University of Cincinnati. 2600 Clifton Ave. 45221, Cincinnati, Ohio, USA. E-mail: potterpe@gmail.com.

2. Departamento de Geografia, Instituto de Geociências, Universidade Federal do Rio Grande do Sul. Av. Bento Gonçalves, 9500, CEP 91.540-

000, Porto Alegre, RS, Brasil. E-mail: verdum@ufrgs.br.

3. Instituto de Geociências, Universidade Federal de Bahia. Rua Barão de Jeremoabo, s/n, Campus Universitário de Ondina, CEP 40.170-

020, Salvador, BA, Brasil. E-mail: michael@cpgg.ufba.br.

4. Departamento de Geografia, Instituto de Geociências, Universidade Federal do Rio Grande do Sul. Av. Bento Gonçalves, 9500, CEP 91.540000. Porto Alegre, RS, Brasil. E-mail: deby_martins@yahoo.com.br.

5. Departamento de Geodésia, Instituto de Geociências, Universidade Federal do Rio Grande do Sul. Av. Bento Gonçalves, 9500, CEP 91.540000, Porto Alegre, RS, Brasil. E-mail: nelsonlisboa@hotmail.com.

Recebido em 07/2011. Aceito para publicação em 07/2013.

Versão online publicada em 04/12/2013 (www.pesquisasemgeociencias.ufrgs.br)

\begin{abstract}
In Brazil drainage patterns and slopes were studied in the Valley of Três Forquilhas near Terra de Areia on the seaward edge of the volcanic plateau of northeastern Rio Grande do Sul. We studied this area to explain why the escarpment of the plateau is closest to the sea here and to establish the erosional history of this small part of the escarpment. Here two small rivers, Três Forquilhas and Maquiné, follow the Torres Syncline to the Atlantic Ocean. These rivers probably started to significantly erode the syncline and the volcanic plateau starting in the Middle to Late Miocene in response to far field Andean tectonics and epirogenic uplift across most of South America. Subsequent erosion probably occurred in pulses rather than at an uniform rate in both watersheds much as short bursts of intense heavy rainfall "pulse" local erosion of the escarpment every few years today. Study of the offshore sequence stratigraphy of the Tertiary fill of the adjacent Pelotas Basin helped us establish this local erosional history (seven unconformity bound sequences, thickness variations between these unconformities, and large scale slumping). Study of an onshore subsurface cross section also identified two paleovalleys in Mesozoic rocks beneath the present valleys of Três Forquilhas and Maquiné Rivers. There is a strong structural control on drainage at all scales. Consideration of slope process contributed significantly to our understanding of drainage evolution and the origin of the escarpment of the volcanic plateau.

Keywords: Três Forquilhas Valley, volcanic plateau, Paraná Basin, Pelotas Basin, Torres Syncline, mass movements, drainage system.
\end{abstract}

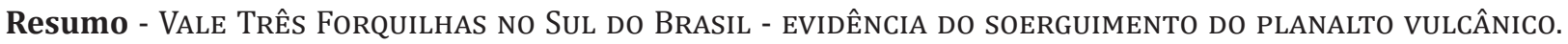
Os padrões de drenagem e a encosta foram estudados no vale do rio Três Forquilhas que é situado próximo da localidade de Terra de Areia, entre o mar e a borda nordeste do planalto vulcânico, no Rio Grande do Sul. Esta área foi estudada para explicar por que a escarpa do planalto vulcânico é mais próxima ao mar nesta sua porção nordeste e estabelecer a história erosional desta porção da escarpa. Aqui dois rios relativamente curtos, os rios Três Forquilhas e Maquiné, seguem a Sinclinal de Torres em direção ao Atlântico. Esses rios, provavelmente, iniciaram a erodir significativamente a sinclinal e a borda do planalto a partir do Mioceno Médio a Superior, em resposta à tectônica Andina de soerguimento tectônico de colisão ao longo da maior parte da América do Sul. A erosão subsequente, provavelmente, ocorreu em pulsos e não em uma fase uniforme em ambos os divisores de águas, muito como as chuvas torrenciais atualmente, que a cada dois ou três anos "impulsionaram" a erosão local da escarpa. 0 estudo da sequência estratigráfica no Terciário quando da sedimentação da Bacia de Pelotas adjacente à área de estudo, nos ajudou a estabelecer esta história erosiva local (sete discordâncias entre as sucessões de depósitos, variações de espessura entre estas discordâncias e a grande escala de espessuras). 0 estudo de uma seção transversal do continente em direção ao litoral identificou dois paleovales em rochas do Mesozoico abaixo do nível de base dos atuais rios Três Forquilhas e Maquiné. Há um controle estrutural forte da drenagem em todas as escalas. Essas considerações sobre os processos que se desenvolvem sobre a vertente contribuem, significativamente, para a compreensão sobre a evolução da drenagem e a origem da escarpa do planalto vulcânico.

Palavras-chave: Vale Três Forquilhas, planalto vulcânico, Bacia do Paraná, Bacia de Pelotas, Sinclinal de Torres, movimentos de massa, sistema de drenagem. 


\section{Introduction}

Long coastal escarpments on passive continental margins are recognized as major global geomorphic features comparable in importance to continent-spanning, Alpine-type mountains. Such escarpments are well developed and best known mostly in southern Africa (Ollier \& Marker, 1985; Partridge \& Maud, 2000), western peninsular India (Widdowson, 1997), and eastern Australia (Bishop, 1988; Ollier \& Pain, 1994). Southwestern Brazil, also a passive margin, has comparable coastal escarpments ranging from Rio de Janeiro to near Porto Alegre, a distance of over $1.500 \mathrm{~km}$, that includes the Serra do Mar and the seaward border of the volcanic plateau of southeastern Brazil. Most of the drainage of this plateau is away from the coast and flows a much longer distance to Buenos Aires via the many tributaries of the Paraná River. "Planalto" is a long used informal name for the lava-sandstone plateau of the Paraná Basin (Ab'Saber, 1969; IBGE, 1990, 1993; Ross, 1990). Other local names used include the: "Planalto Meridional", "Planalto Basáltico" and "Planalto do Paraná".

We studied only a very small portion of this escarpment where it comes closest to the South Atlantic Ocean in the Torres Syncline of northeastern Rio Grande do Sul and adjacent Santa Catarina states (Figs. 1 and 2). We chose this area for two reasons: there is some rare subsurface data here both on and offshore and here the escarpment is closest to the sea, it is only separated from the South Atlantic Ocean by a $13 \mathrm{~km}$ wide stripe of coastal lagoons, swamps, well developed beaches and some low dunes. The escarpment rises abruptly $800 \mathrm{~m}$ above this coastal landscape. Here two small, parallel rivers Três Forquilhas and Maquiné (Fig. 3) flow directly into the coastal lagoons, both in spectacular, short valleys, where the watershed of Três Forquilhas River covers about $380 \mathrm{~km}^{2}$ and that of Maquiné River $422 \mathrm{~km}^{2}$. Both watersheds are almost all in slopes. Included in the study are adjacent portions of the volcanic plateau most of which drains inland and a small area of eastward drainage of the headwaters of Mampituba River, which flows into Santa Catarina. The northward and inland drainage behind the rim of the escarpment is into the Tainhas River, a tributary to the Antas-Taquari River which drains some $340 \mathrm{~km}$ southwest into the Jacuí River and the Guaíba Lagoon near Porto Alegre. This setting suggests three questions - why is the escarpment so close to the sea here, how were the twin valleys of Três Forquilhas and Maquiné Rivers localized, and when were they so spectacularly entrenched? The last of these questions is directly related to the time of uplift of the volcanic plateau. Because both valleys appear to be identical twins, we focused on the valley of Três Forquilhas.

To answer these questions we turned first to regional geology, used the 1:50,000 topographic maps of the Tainhas, Aratinga, Três Cachoeiras, Barra do
Ouro, Maquiné and Arroio Teixeira quadrangles plus two 1:100,000 geologic quadrangles (Horn Filho et al., 1984a and b) some special kinds of spatial images, environmental and engineering reports (Har Engenharia, 1990; Figueró et al., 1998), onshore core drilling and offshore seismic sections plus insights from the Neogene uplift history of South America.

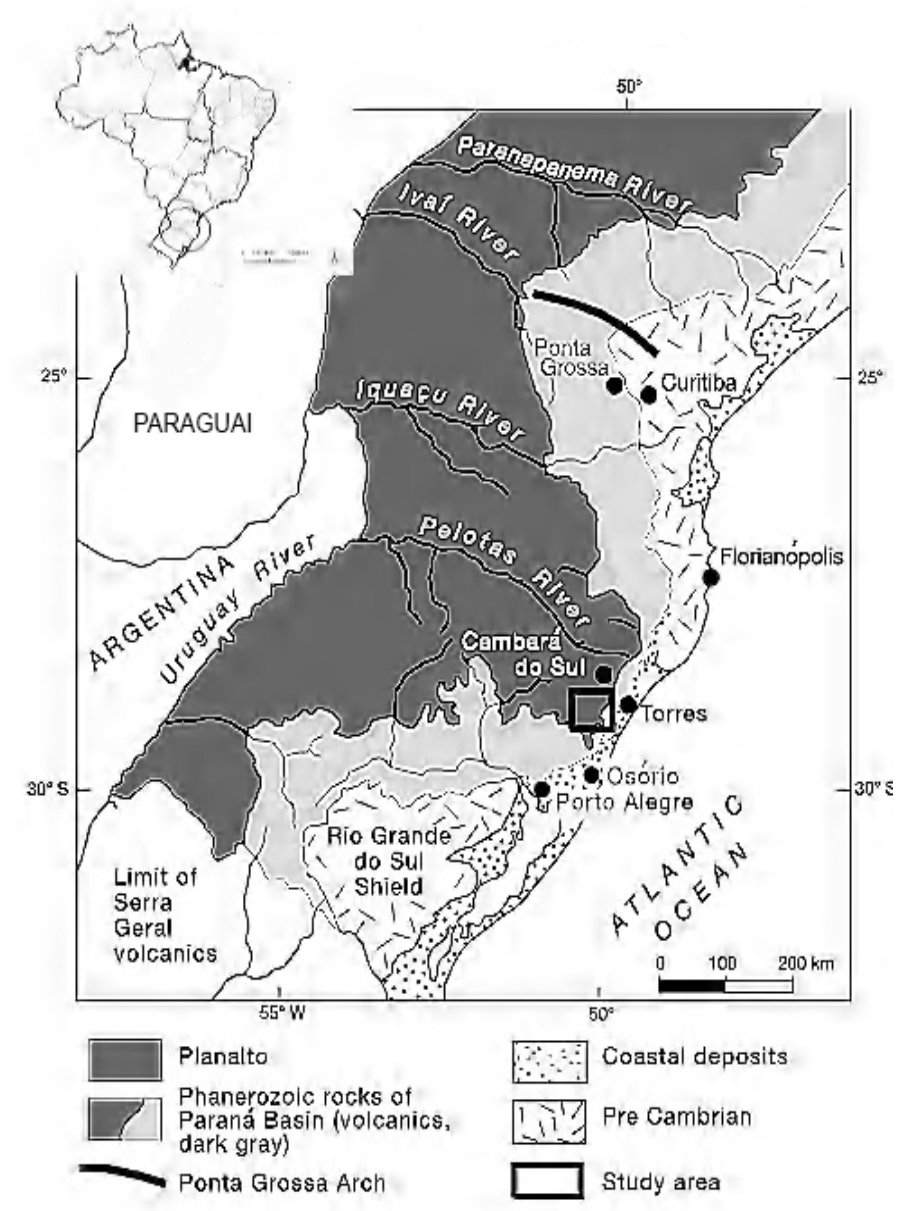

Figure 1. The State of Rio Grande do Sul on the passive margin of South America. Regional setting, major structural features (Ponta Grossa Arch, Sul-Rio-Grandense Shield) and study area.

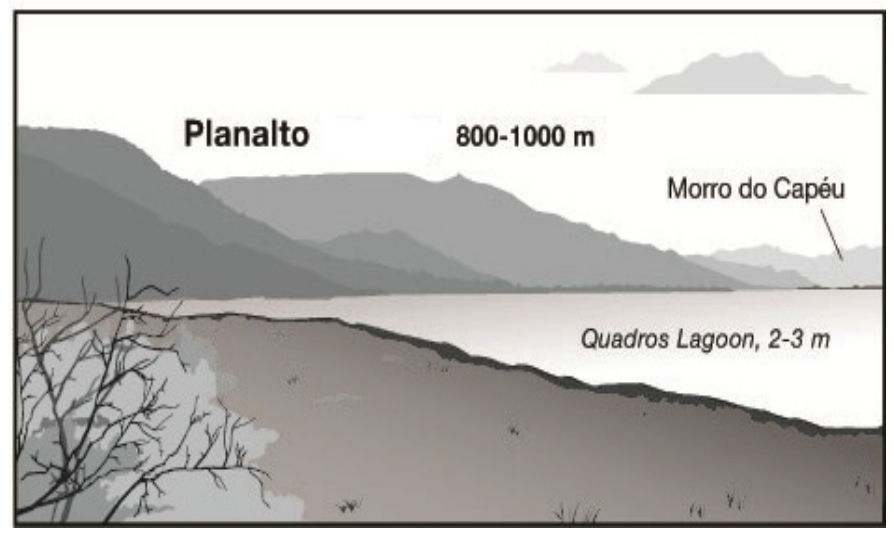

Figure 2. Looking northeast along the dissected front of the volcanic plateau from the shores of Quadros Lagoon. 


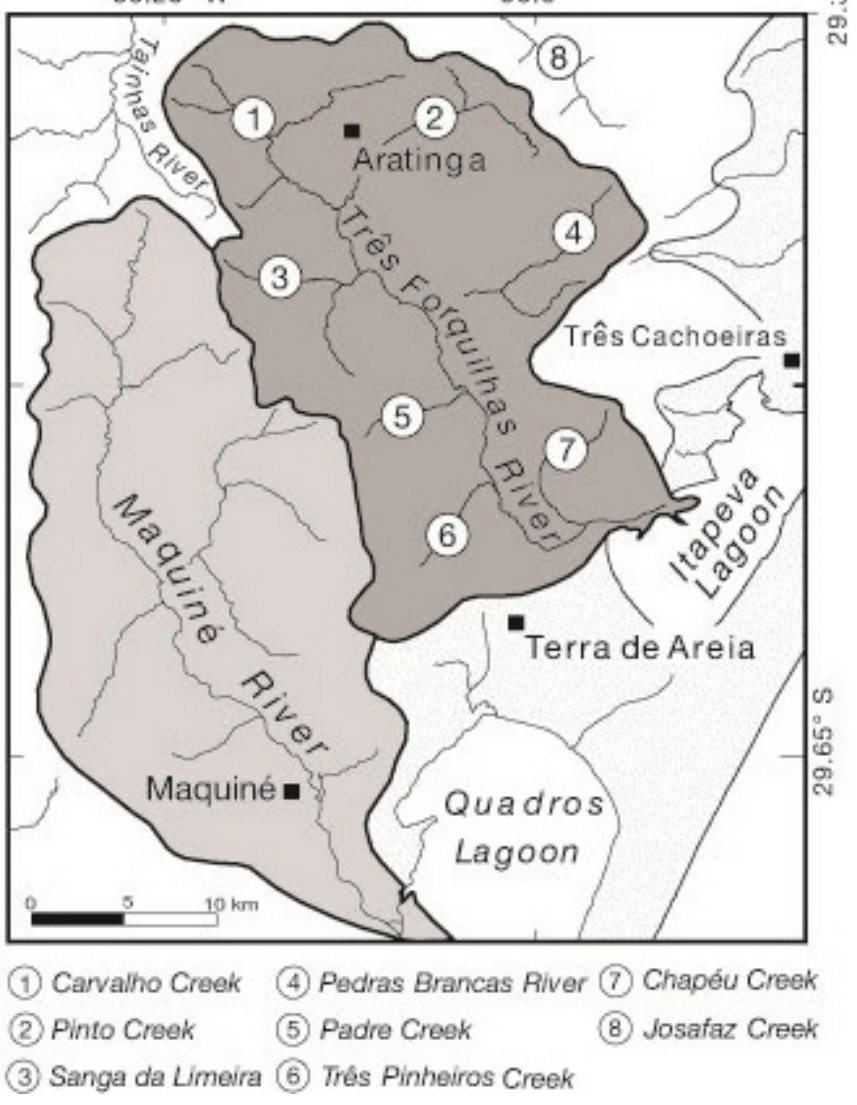

Figure 3. Watersheds of Três Forquilhas and Maquiné rivers.

\section{Regional setting}

\subsection{Geology}

The Torres Syncline (Fig. 4 - A, B, C) lies about half way between two major regional structural features, the Ponta Grossa Arch to the northeast and the Sul-Rio-Grandense Shield to the southwest. Both directly influence the morphology of the valley and the location of the escarpment and thus affect its retreat. To the northeast the Ponta Grossa Arch carries the escarpment to over $1600 \mathrm{~m}$ above sea level and Proterozoic, mostly crystalline rocks extend inland to about $350 \mathrm{~km}$, while to the southwest of the Torres Syncline, the Sul-Rio-Grandense Shield is the dominant structural feature and also causes the escarpment to extend inland some $370 \mathrm{~km}$. As traced southwestward from Santa Catarina, the volcanic plateau and its escarpment become gradually lower. Above the Precambrian basement in the Torres Syncline is a thin section of Upper Paleozoic and Mesozoic rocks, mostly sandstones, of which only the Jurassic-Cretaceous Botucatu Sandstone, an eolianite (Almeida, 1952; Scherer, 2000), has a few outcrops in and near the syncline. In Três Forquilhas Valley all the outcrops of the Botucatu are near the city of Terra de Areia and none are higher than $60 \mathrm{~m}$ above sea level. Overlying the Botucatu are about 700 to $900 \mathrm{~m}$ of lava flows of the Jurassic-Cretaceous Serra Geral Formation (Fig. 5), the widespread flood volcanics of the intra cratonic Paraná Basin (Bellieni et al., 1986; Mantovani et al., 2000; Milani \& Zalán, 2000). These flows cover an area of about 1,100,000 km² in Brazil, Argentina, Paraguay, and Uruguay and everywhere form a distinctive escarpment (Fig. 1). Locally, in the Torres Syncline there appear to be between 15 to $20 \mathrm{~m}$ such flows in the escarpment some of which, in the upper part of the section, can be traced as far as 10 to $15 \mathrm{~km}$ or more. In the lower half of the escarpment their composition is dominantly that of basalt, but higher in the section rhyolite is dominant and there are even some glass-rich flows (Belliene et al., 1986; CPRM \& FEPAM, 1998; Mantovani et al., 2000). These compositional variations, along with variations in texture and fracture density, markedly affect the weathering profile of the escarpment and the surface processes acting on it. The upper acid flows form prominent, near vertical cliffs (Fig. 6), some as high as 30 to $40 \mathrm{~m}$ or more, and have steep intervening slopes, whereas the lower slopes developed on basalt, have fewer cliffs, gentler slopes and thicker colluvium. Consequently, the overall topographic profile of the escarpment steepens upward as its volcanic rocks change from easily weathered basalt to more resistant acid volcanic.

The study area has three prominent fracture sets, the strongest generally trends $\mathrm{N} 60^{\circ} \mathrm{E}$ and is approximately at right angles to the trend of Maquiné and Três Forquilhas rivers and Josafaz Stream (Fig. 7). Other fracture systems trend $\mathrm{N} 10^{\circ}-20 \mathrm{E}$ and $\mathrm{N} 40^{\circ}-50^{\circ} \mathrm{W}$ (Figueró et al., 1998). The $\mathrm{N} 60^{\circ} \mathrm{E}$ fracture system strongly influences drainage systems at virtually all scales and also may be related to the origin of the abrupt termination of the escarpment above the coastal plain (Figs. 2 and 7).

Unconsolidated Quaternary sands, silts and muds form a narrow $13 \mathrm{~km}$ wide, coastal plain between the base of the escarpment and the South Atlantic Ocean and consist of a large Holocene coastal sandy barrier behind which are several large shallow lakes, swamps, a few small isolated dune fields and some low scattered terrace deposits and remnants of coastal barriers at the base of the escarpment (Horn Filho et al., 1984a and b). Except for a few dunes and low terraces, most of this coastal plain is only a few meters above sea level, although the city of Terra de Areia lies on a low terrace some 10 to $15 \mathrm{~m}$ above sea level. The general geology of the unconsolidated coastal deposits is summarized by Villwock \& Tomazelli (1995). Below these coastal plain sediments are about $1000 \mathrm{~m}$ of Triassic and Permian sediments above Precambrian basement (Aboarrage \& Lopes, 1998), fig. 4A. This thicker section of Permian and Triassic sediment preserved beneath the Torres Syncline shows that a low has been in existence as a topographic low since at least since the Triassic.

The Pelotas Basin, a marginal Atlantic Basin (Dias et al., 1994; Fontana, 1990, 1996; Cainelli \& Mohriak, 1998), lies offshore and extends the length of Rio Grande do Sul State into Santa Catarina State almost to Florianópolis. The Pelotas Basin is known from 17 
wells and from extensive seismic study. It contains a Cretaceous section and thick Cenozoic section. We found the stratigraphic sequence and geologic history of the Tertiary fill of the Pelotas Basin to be essential for understanding nearby Tertiary erosional history onshore.

In broad overview, the relief of Rio Grande do Sul State and most of southeastern Brazil has been assigned to four major erosion surfaces or cycles - Gondwana, Post Gondwana, Sul Americana and Velhas - following King (1953, 1956), Ab'Saber (1969) and Justus et al. (1986). We tentatively recognize in the study area the volcanic plateau as a Sul Americana surface. In our study area elevations of the plateau surfa- ce range from about $880 \mathrm{~m}$ in the southwest to more than $1020 \mathrm{~m}$ in the northeast (Fig. 8). These surfaces are defined by elevation, dissection, distance from the sea and weathering crusts. Only remnants of the plateau remain in most of the watershed of Três Forquilhas so that most of it is in slopes (Fig. 9). In addition, there are minor remnants of a surface between 200 and 300 $\mathrm{m}$, probably the Velhas surface. The Sul Americana surface has been considered to range from Cretaceous to Pliocene in age and the Velhas to be Plio-Pleistocene in age (Brown, 1971). Everywhere in the study area the topographic contrast between the plateau and direct Atlantic drainage to the southeast is clear and great as are contrasts in soils and surface processes (Table 1).
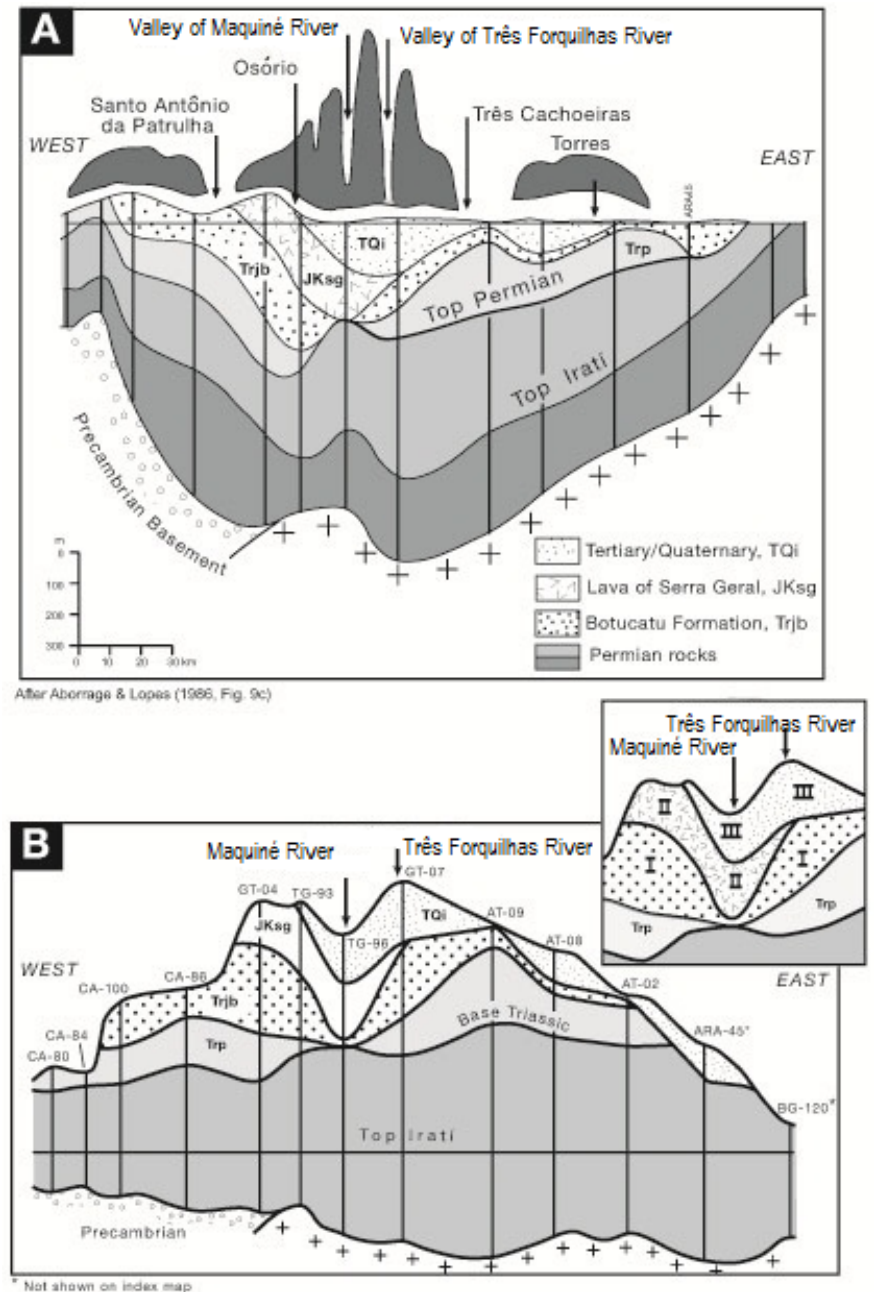

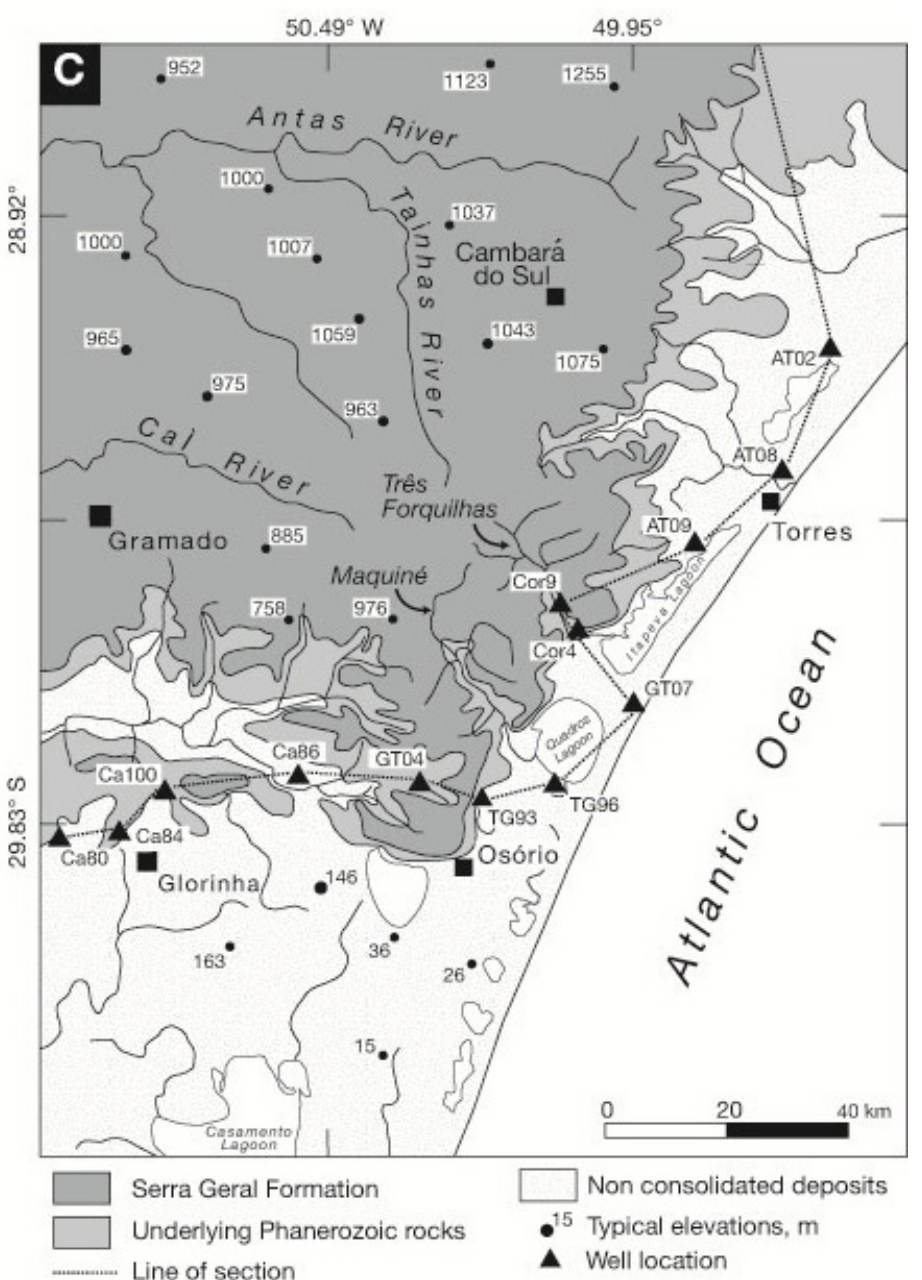

Figure 4. Cross sections based on Aborroage \& Lopes (1998, fig. 96): A) Structural cross section and topography of Torres Synclinal seen from the coast; B) stratigraphic cross section using the middle of the Irati Formation as a level line; C) plateau surface (gray) with line of cross sections A and B. Note the three paleochannels below the location of Três Forquilhas River. 

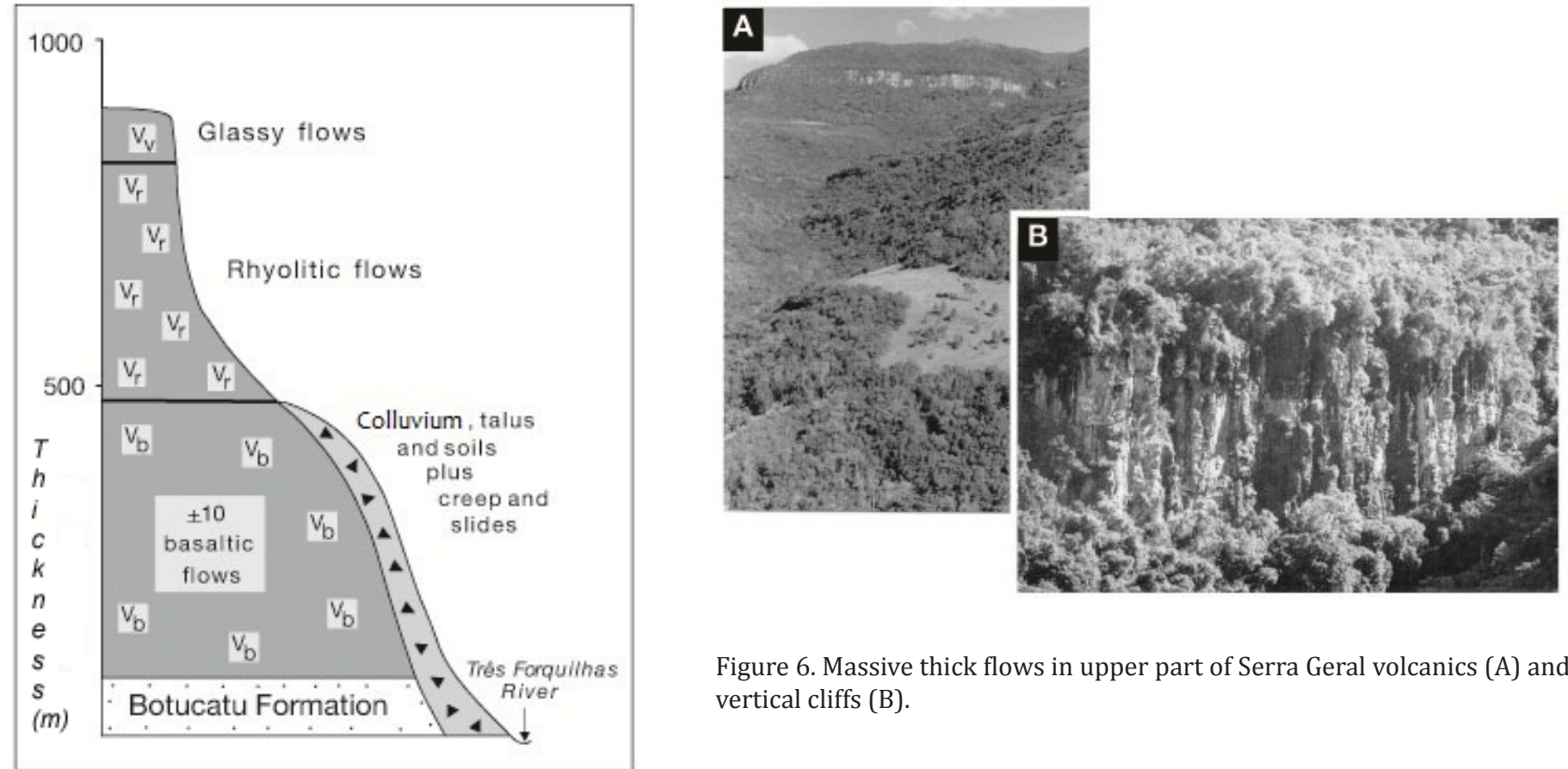

Figure 6. Massive thick flows in upper part of Serra Geral volcanics (A) and vertical cliffs (B).

Figure 5. Generalized stratigraphic column of Serra Geral Formation near Terra de Areia, Rio Grande do Sul.

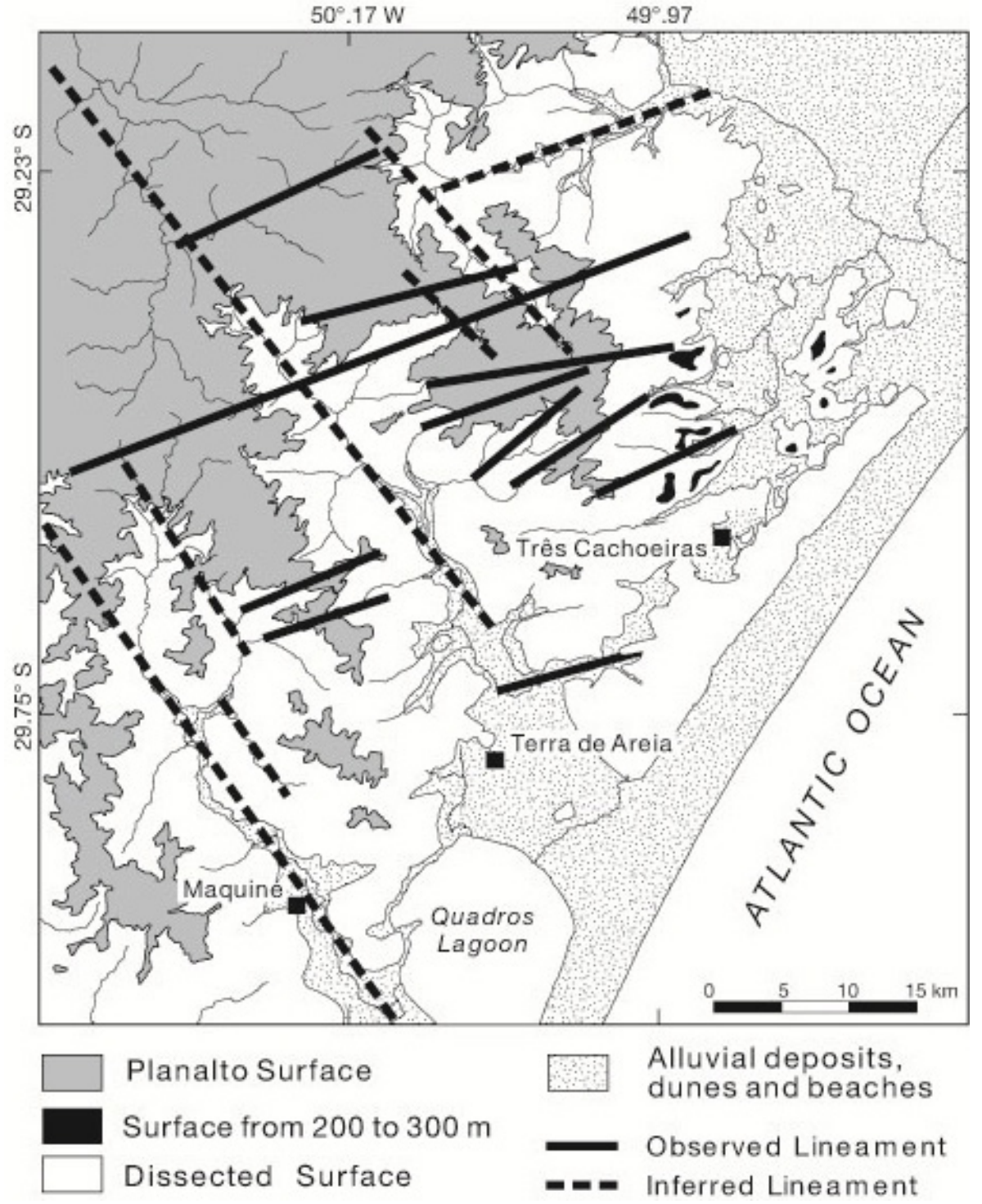

Figure 7. Fractures and geomorphology in the study area. 


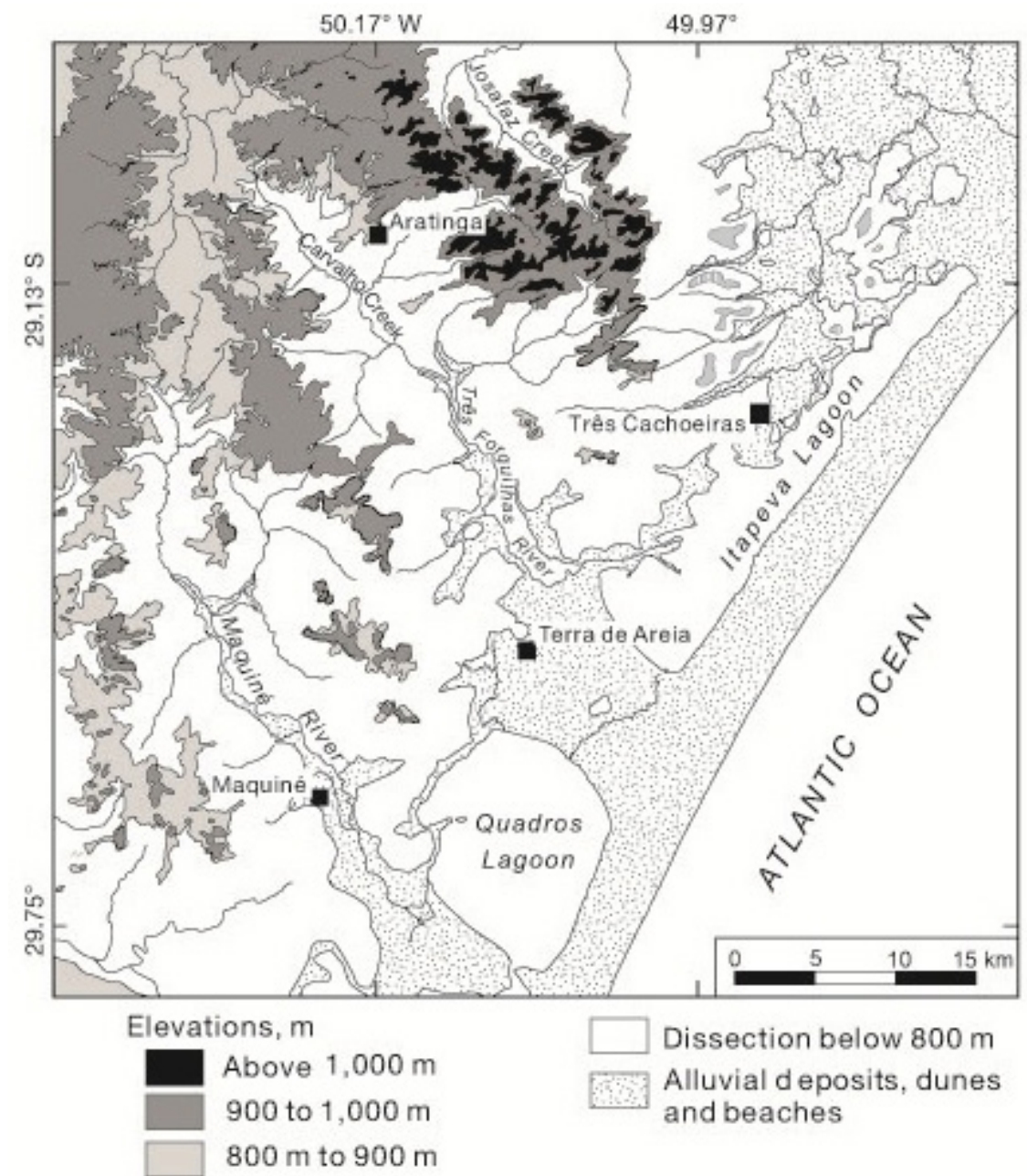

Figure 8. Generalized elevations of the volcanic plateau surface rise to the northeast toward the Ponta Grossa Arch.
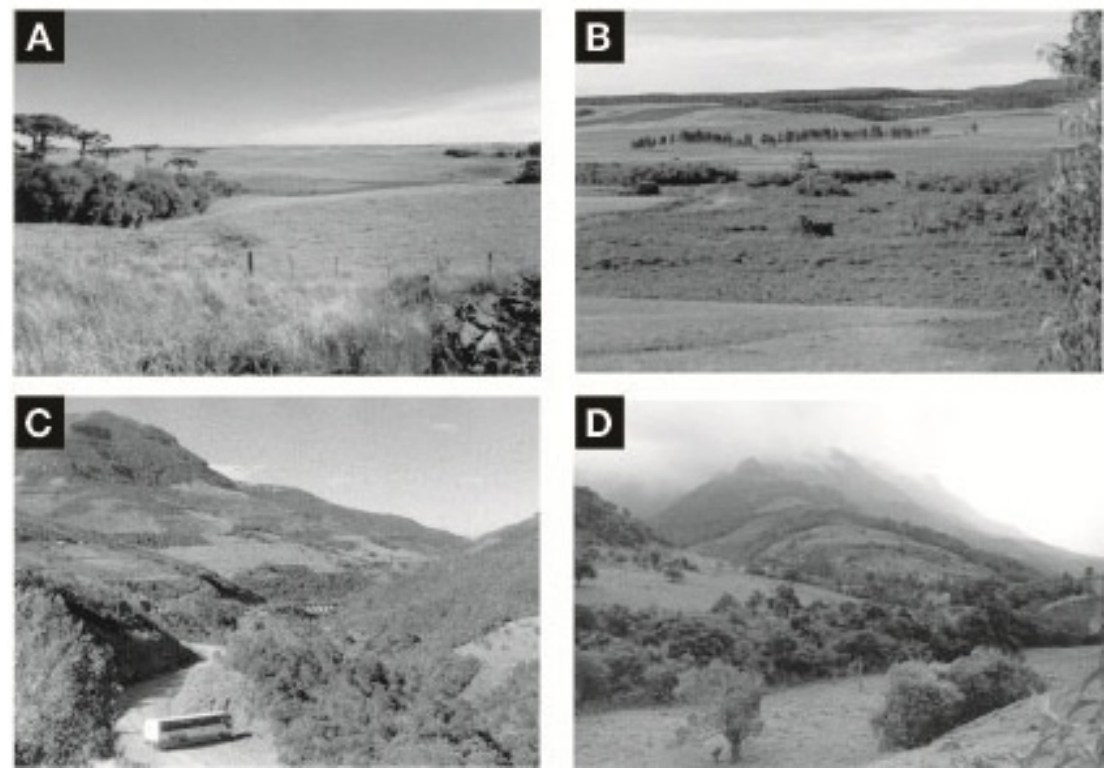

Figure 9. Plateau surface and its dissection: A) typical topography of the volcanic plateau east of São Francisco de Paula a few kilometers northwest of its scarp; B) wide valley of Antas-Taquari River draining the back slope of the plateau about $18 \mathrm{~km}$ from its scarp (note open, shallow, swampy valley and contrast with narrow valleys flowing directly to the Atlantic Ocean); C) and D) valleys of streams flowing directly to the Atlantic in front of the scarp. 


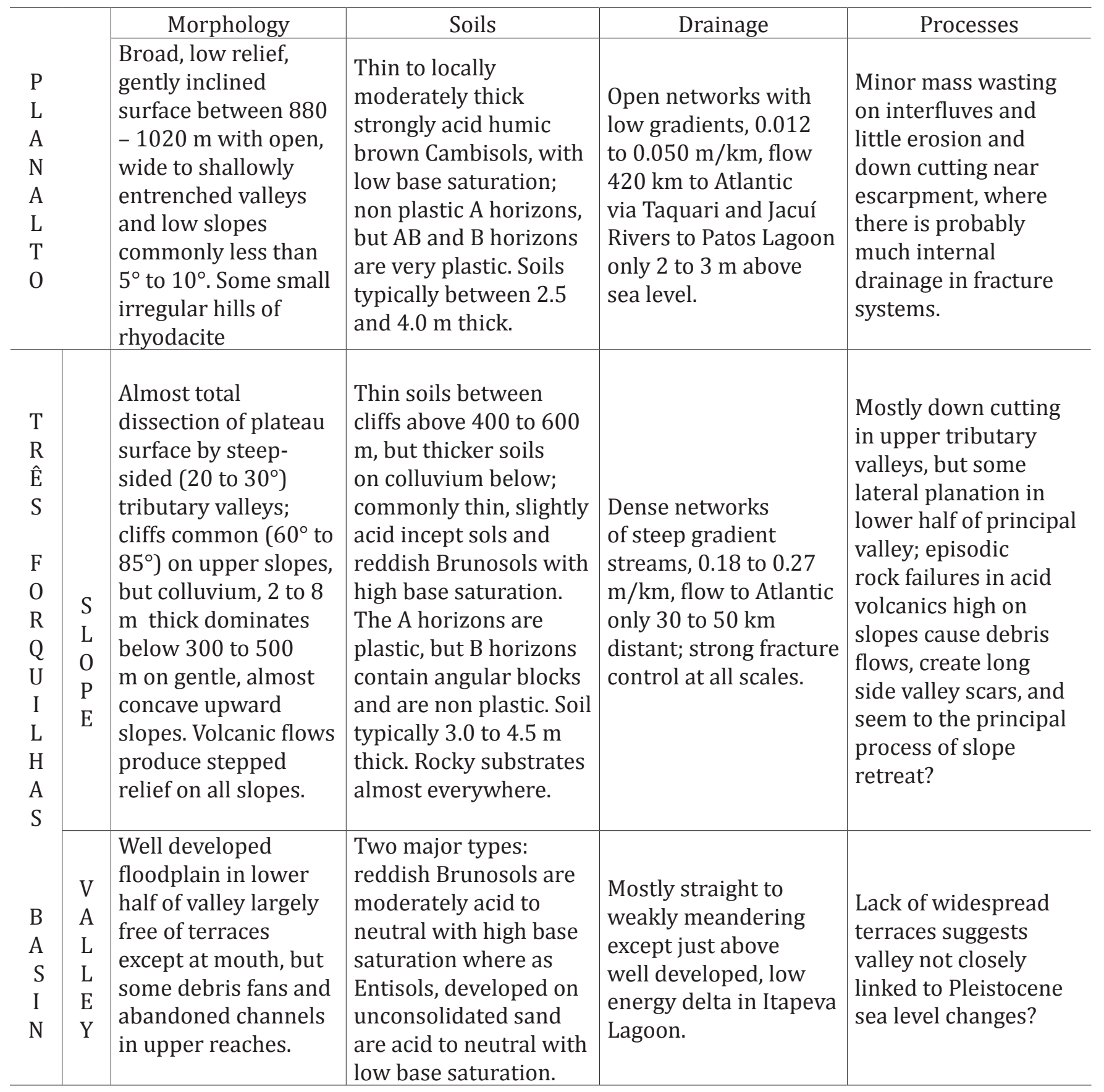

\subsection{Climate and Vegetation}

The valley of Três Forquilhas River has a subtropical climate with marked seasons; summers typically have temperatures between 25 to $30^{\circ} \mathrm{C}$ and winters between 5 and $15^{\circ} \mathrm{C}$. Average rainfall in the valley is $1800 \mathrm{~mm}$ (one of the wettest regions in Rio Grande do Sul). Year to year variation is great, however; for example, between 1975 and 2010 the driest year at Terra de Areia had $970 \mathrm{~mm}$ of rainfall and the wettest 2768 $\mathrm{mm}$, almost three times as much. Intense rainfalls have also been recorded and, because of the great local relief, they play an important role in local geomorphic processes. It is intense single and successive day rainfall; however, that saturates slopes to failure. In Três Forquilhas Valley, single day rainfall maxima (Table 2) range from 91 to $206 \mathrm{~mm}$ for the years 1975 to 2010 . Successive days of high rainfall are more dangerous and damaging, however, because after the first day of high rainfall, the soil is already largely or totally saturated. For example, in 2010, $324 \mathrm{~mm}$ in 11 days caused widespread slope failures and debris flows (data from Departamento Nacional de Águas e Energia Elétrica DNAEE and Companhia de Pesquisa de Recursos Minerais - CPRM, 1975-2010).

Three types of vegetation are recognized in the valley of Três Forquilhas. These vary with landscape, altitude and climate and are the Campos de Cima da Serra (the open grasslands of the volcanic plateau) and the Araucária and Atlantic Forests of which the Atlantic is the most widespread. Originally these two forests covered all the valley floor and all but the steepest slo- 
pes and cliffs of Três Forquilhas Valley. Today, however almost all of the valley bottom and most of the lower slopes have been cleared. See IBGE (1993, p. 123-129), Domingos (1997) and Verdum (2009) for detailed descriptions of vegetation and its distribution in coastal southern Brasil.

Key for geomorphology is that Atlântica and
Araucária Forests have dense understory of vegetation that reduce runoff; these two forest types also and equally have dense interpenetrating networks of roots that bind and stabilize soil and colluvium. Where this forest has been cut, however, this root system rots and, after a few years, soil and colluvium are much less resistant to creep and failure.

Table 2. Extreme Rainfall (mm) at Terra de Areia 1975 to 2010 (Data from DNAEE and CPRM, 1975-2010).

\begin{tabular}{rl}
\hline \multicolumn{1}{l}{ Single Days } & Sequential Days \\
\hline $94-24 / 02 / 75$ & \\
$75-12 / 05 / 76$ & $162-12,13 \& 14 / 12 / 75$ \\
$84-21 / 07 / 80$ & $159-11,12 \& 13 / 05 / 76$ \\
$140-03 / 12 / 80$ & $176-12 \& 13 / 06 / 83$ \\
$125-28 / 06 / 82$ & $192-16,17 \& 18 / 06 / 84$ \\
$136-13 / 06 / 83$ & $198-13 \& 14 / 05 / 94$ \\
$140-09 / 08 / 85$ & $130-05 \& 06 / 11 / 99$ \\
$150-21 / 02 / 93$ & $124-29 \& 30 / 11 / 02$ \\
$100-14 / 05 / 94$ & $108-22,23 \& 24 / 03 / 05$ \\
$120-05 / 11 / 99$ & $180-18,19 \& 20 / 11 / 06$ \\
$116-04 / 10 / 00$ & $165-01$ to $04 / 03 / 07$ \\
$103-29 / 11 / 02$ & $231-16$ to $21 / 03 / 07$ \\
$103-04 / 05 / 04$ & $202-02,03, \& 04 / 01 / 09$ \\
$108-20 / 11 / 06$ & $324-14$ to $24 / 02 / 10$ \\
$117-04 / 03 / 07$ & \\
$142-22 / 04 / 08$ & \\
$122-03 / 01 / 09$ & \\
\hline
\end{tabular}

\section{Results}

\subsection{Drainage pattern and profiles}

There is a close relation between drainage pattern and structure in the Torres Syncline that is apparent at all scales (Figs. 4 and 7). Both the Três Forquilhas and Maquiné Rivers flow south observation shows dips up to $15^{\circ}$ along some of the straight reaches of these small streams as reported elsewhere in the Paraná Basin. Thus it seems that many, perhaps all, of the larger tributaries in the watershed of Três Forquilhas and nearby developed along important fractures in underlying densely fractured bedrock; this greatly facilitated down cutting and headward stream erosion into the plateau surface. Notable is that the eastern tributaries of Três Forquilhas River are longer than its western ones. Could this be a consequence of flowing downdip on steeper gradients of the eastern limb of the syncline? Overall, the fracture-lineament system in the study area is directly responsible for its rectangular-dendritic to directional-trellised drainage pattern (Howard, 1967). Also of importance is that west of the watershed of Maquiné River, drainage parallels the coast and flows into Patos Lagoon, a distance of about $160 \mathrm{~km}$, rather than flowing directly into the Atlantic. On a much smaller scale, this mirrors closely the drainage pattern of the Uruguay and Paraná Rivers, both of which take the "long way" to the Atlantic (Araújo et al., 1999).

Another example of drainage away from the escarpment rim is the northward drainage down its backslope into the headwaters of the Antas-Taquari River. Here drainage pattern is mostly open and dendritic (instead of dense, steep and subparallel on the front of the volcanic plateau) and gradients are low. These shallow valleys on the plateau are separated by a few low, irregular scattered hills of acid volcanics. Although outside of the main volcanic plateau and now draining directly to the Atlantic, Josafaz Stream flows northwest $13 \mathrm{~km}$ following a fracture before abruptly turning eastward to the Atlantic (Fig. 8). We interpret this northwest trending segment of Josafaz Stream to be a relic of an earlier tributary to the Antas-Taquari River before its capture by the Mampituba River in the present cycle of erosion. The main trunk of the Três Forquilhas River and its principal tributaries appear to lack any significant knickpoints except at the lip of the plateau surface, where there are two short tributaries of an earlier cycle of erosion (Fig. 10).

In sum, the watersheds of Três Forquilhas and Maquiné Rivers are limited by the Torres Syncline and flow sub parallel to its axis following fractures or faulting to the nearby South Atlantic Ocean, whereas many of their larger tributaries are localized by the densely spaced, south-southwest trending fracture system. Be- 
cause the lithologies are similar in the two watersheds, so too are their stream densities. Lack of knickpoints in longitudinal profiles points to a landscape in equilibrium.

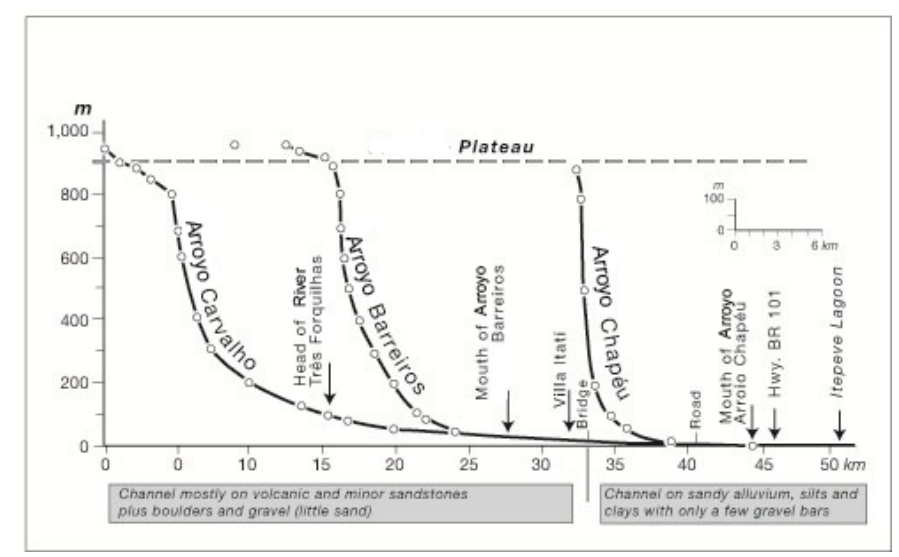

Figure 10. Longitudinal profiles of Três Forquilhas River and its three principal tributaries. Note low remnant gradients in several headwaters upstream from knick points at edge of volcanic plateau.

\subsection{Slopes}

The study of slopes in the watershed of Três Forquilhas Valley provided many insights to the surface processes that act on the escarpment of the plateau and how it retreats. These processes of mass wasting include creep, rotational and translational slides, rock falls and debris flows (Hunt, 2005, table 1-9; Filho \& Virgili, 1998, Ch. 15). The different lithologies of the Volcanic Plateau (basalts and rhyolites) control the weathering processes and, consequently, the topographic profile. Very broadly, the valleys of rivers Três Forquilhas and Maquiné and their larger tributaries all share a common cross valley profile - an upper part consisting of near vertical cliffs, some as high as 30 to $40 \mathrm{~m}$ separated by steep slopes above a lower, almost convex upward, smoother profile that largely lacks cliffs. These two parts reflect not only a compositional change in the flow composition (more acid above and more basic below), but also different surface processes as well. In addition rock falls from acid cliffs high on the escarpment form prominent, long landslide scars with debris flows at their base. Thin colluvium on upper steep slopes has mostly shallow translational slides whereas low on the escarpment rotational slides in thicker colluvium prevail. Creep, on the other hand, occurs on all the slopes, but is most important low on the escarpment where colluvium is the thickest (Fig. 5). Where deforested, these lower slopes have many small shallow rotational slumps as well as some deep ones in their thicker colluvium. In addition, there are a few prominent, long landslide scars that extend from the acid volcanics high on the escarpment to the bottom of large tributaries such as Pinto Stream, where they terminate in debris cones some of which displace the principal stream of the valley.

The sudden release of debris from high above is typically funneled into the steep channel of a first order stream, where it erodes all unconsolidated material down to bedrock to form a distinctive, long scar (Fig. 11). See Figueró et al. (1998) for a good summary of surface processes on the lower slopes and how the different volcanic rock types weather and affect construction. In addition, an alternating wet and dry climate in the Quaternary has been inferred from both valley-side deposits and their topographic profile in nearby Santa Catarina and Paraná States - see the summary by Clapperton (1993, p. 221-228) and the original research by Bigarella \& Mousinho (1966). Thus we fully recognize that the slope deposits of Três Forquilhas Valley have a history - have a stratigraphy - that deserves consideration in future studies. Fundamental to understanding slope processes in the valley is the degree of fracturing of its underlying flows, their capacity to transmit water and their susceptibility to chemical weathering (Chart 1). There is still another key factor - whether the flows locally dip into the valley or away from it (Fig. 12). Whether or not a flow brings water (is an aquifer) to a slope is important, because wet slopes are much more likely to fail than dry ones - wet colluvium weighs more and also has lower effective stresses (Hunt, 2005, p. 721-722).
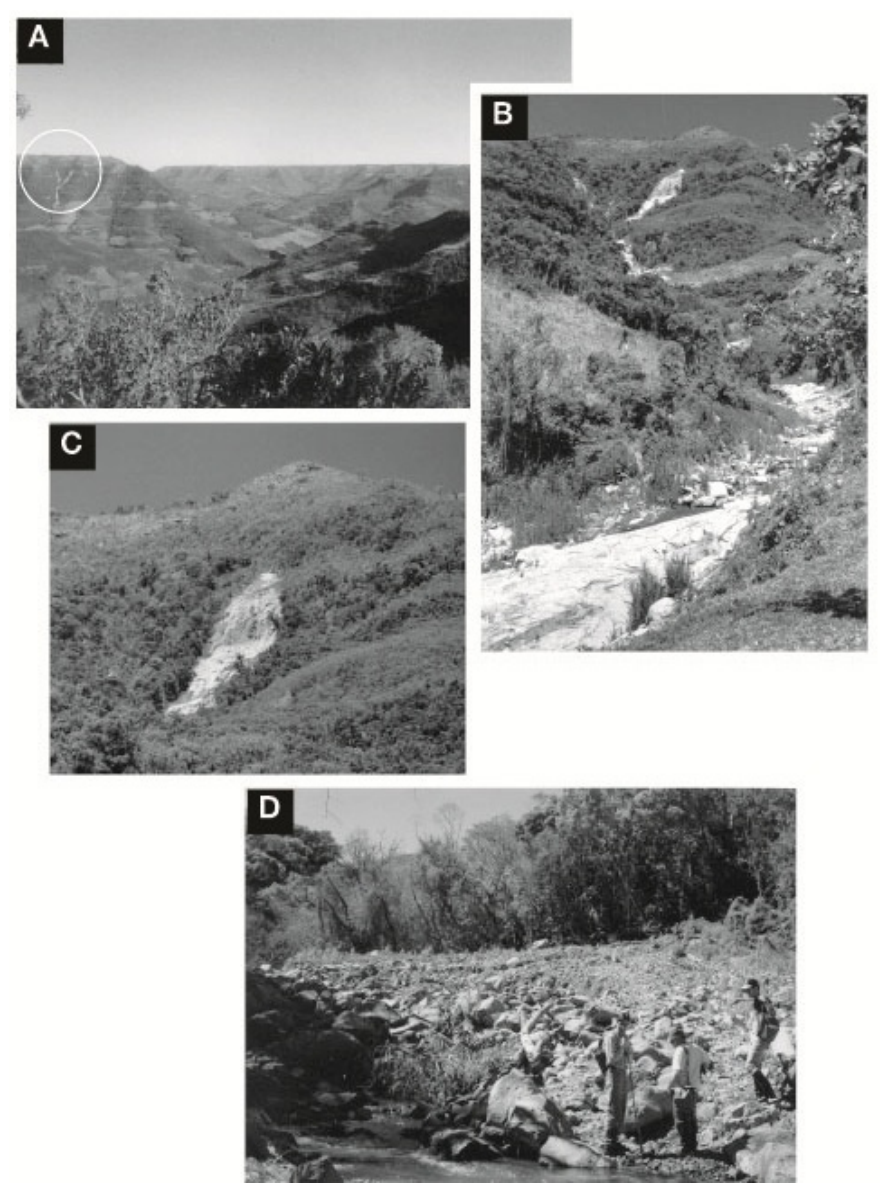

Figure 11. Debris scar and valley bottom deposit in Pinto Stream south of Aratinga. 


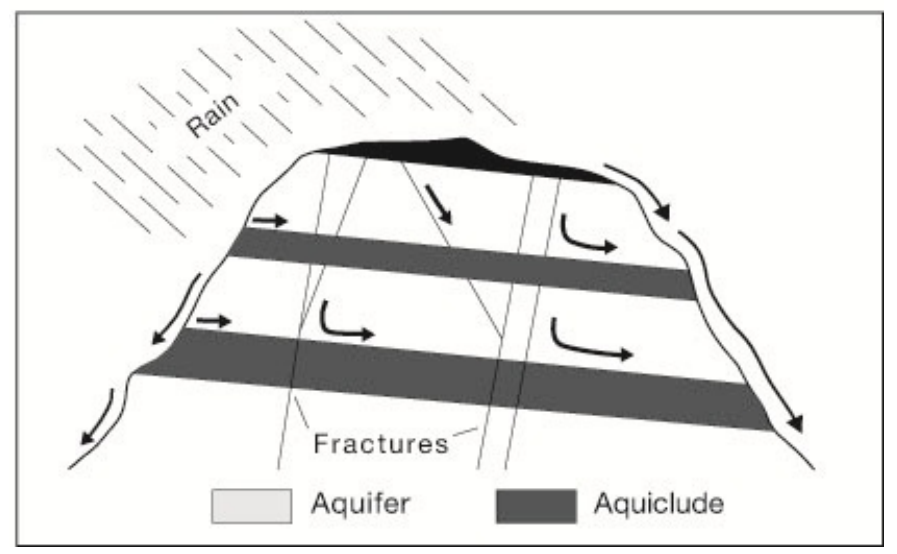

Figure 12. Gentle dips of fractured lava flows can bring water to a hillside, when the dip is toward the valley.

Chart 1. Geomorphic and engineering characteristics of lava flows (adapted from Figueró et al., 1990).

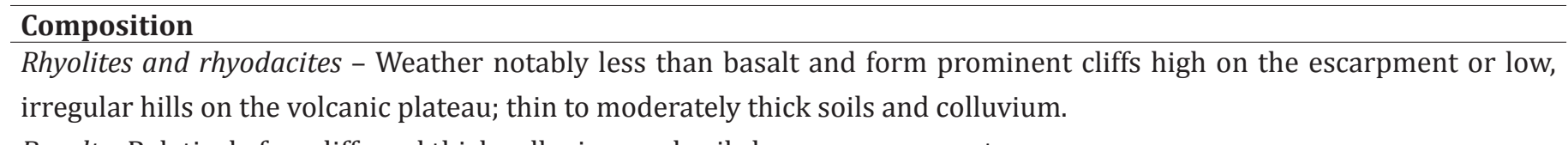

Basalt - Relatively few cliffs and thick colluvium and soils low on escarpment.

\section{Structure and Texture}

Hard, dense and fresh rocks

Little fractured - Weather slowly into large blocks; likely to form a ledge or cliff and be an aquiclude.

Much fractured - Mechanically unstable, closely packed blocks, which weather rapidly; may form steep talus and commonly transmit much water.

Amygdaloidal beds - Commonly fairly thin, but likely to be aquicludes unless much fractured.

Volcanic breccias - Tend to be aquifers, especially where fractured.

Glasses - Weather readily to clay and form reentrants; generate much colluvium

Laminated rocks - Weather chemically and physically more rapidly than massive acid or basic volcanic rocks

Paleosoils and altered rocks - Act as aquicludes and readily form colluvium were exposed. Sandstones are thin and uncommon, but are good aquifers

Where aquifer beds dip into a slope, they may drain water from it (if colluvium is neither too thick nor too impermeable), but where they dip toward the slope, they add water to it - not only during rains, but throughout the year - so that wet colluvium and soil are never too far from failure. Conversely, where water is diverted from a slope, colluvium and soil can adsorb much more water from a rain and thus be less likely to fail. In either case, the more fractured the aquifer, the greater its transmission of water and its internal solution and weathering (yielding more expandable clays), all of which contribute to additional instability. Greater density of fractures also produces smaller blocks that weaken a face. Additionally, near vertical to sub vertical fractures that dip toward a valley reduce its stability more than those that dip into the side of the valley. In Três Forquilhas Valley, the worst case for failure is a well fractured flow dipping into the valley. Because of the extensive vertical fracture system of the lavas of the Serra Geral Formation and the great local relief of the valley, a fractured flow dipping into a slope can collect water with a high hydraulic head from a wide area and thus will bring an enhanced flow rate to its outcrop and quickly destabilize it.

Topographic cross sections provided insight for a better understanding of slope processes (Fig. 13AC). Eight cross sections were made in the watershed of Três Forquilhas River and three outside of it. These were constructed from enlargements of the 1:50,000 topographic maps. Spacing of control points varies with slope ranging from 0.1 to $0.95 \mathrm{~km}$ apart for much of the plateau to as close as $0.05 \mathrm{~km}$ for some of the steepest slopes depending on topography (Fig. 13B). For Três Forquilhas Valley, these sections always began and ended at the plateau surface or close to it. All sections were made along interfluves. 

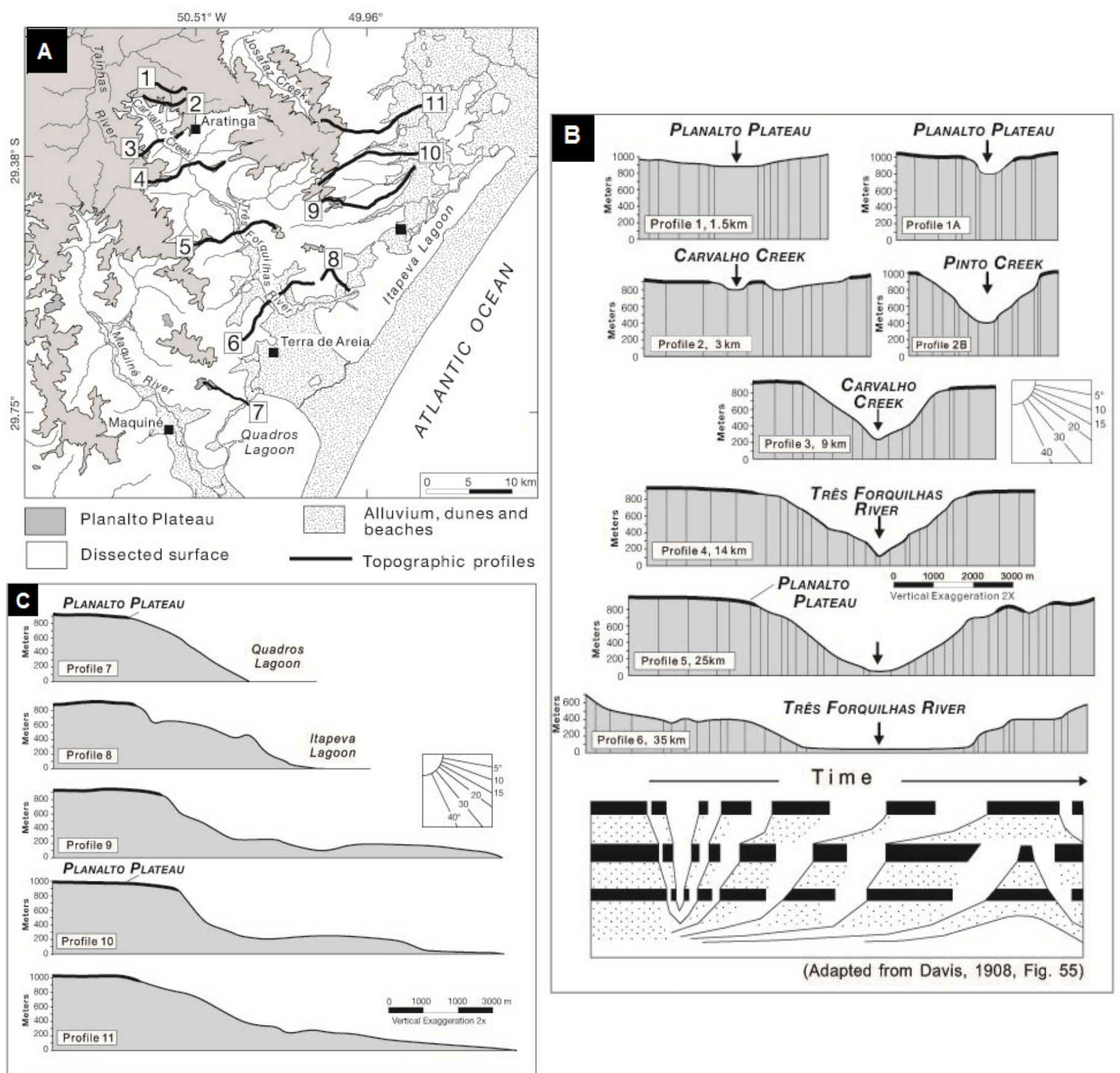

Figure 13. Topographic cross sections: A) index map to cross sections; B) Três Forquilhas valley and similarity to the model of parallel retreat (Davis, 1908, apud King \& Schumm, 1980) and; C) possible Velhas surface just to the east of the watershed.

Sections $1,1 \mathrm{~A}$ and 2 are at right angles to small, first order tributaries that drain to the Atlantic, relic stream valleys not yet consumed by the new encroaching cycle of erosion. Profile 2 illustrates rapid entrenchment just below the escarpment only $4.6 \mathrm{~km}$ downstream. Here valley sides slope at about $30^{\circ}$. Profiles 3 and 4 are 9 and $14 \mathrm{~km}$ downstream both with distinctly wider valleys. Along profile 4 , slopes range from $5^{\circ}$ to $45^{\circ}$. Profile 5 has an even wider valley with a convex upwards surface while Profile $6.35 \mathrm{~km}$ downstream, lacks remnants of the volcanic plateau surface, shows a broad bench at about $450 \mathrm{~m}$ and has a wide flood plain of 3 to $4 \mathrm{~km}$. Sections 7 and 8 (Fig. 13C) extend down the front of the escarpment into Quadros and Itapeva Lagoons. Here, in all of southern Brazil, the volcanic plateau is closest to the Atlantic. In profile 7 the escar- pment slopes uniformly seaward and in only $4 \mathrm{~km}$ elevations decrease from over $800 \mathrm{~m}$ to almost sea level. Profile 8 has a similar, but more irregular, abrupt descent to sea level. Two detailed profiles of isolated, small hills provide detailed insight to the above topographic cross sections (Fig. 14).

We also made three cross sections, profiles 9, 10, and 11, along the east side of the escarpment just outside of the Três Forquilhas watershed, These show a distinct shoulder, a surface between 200 and $300 \mathrm{~m}$, possibly the Velhas surface, along the east side of the escarpment as it trends north of Três Cachoeiras. This distinct surface, 2 to $4 \mathrm{~km}$ wide and over $10 \mathrm{~km}$ long, parallels the east side of the escarpment and overlooks the broad lowland drained by Mampituba River. 


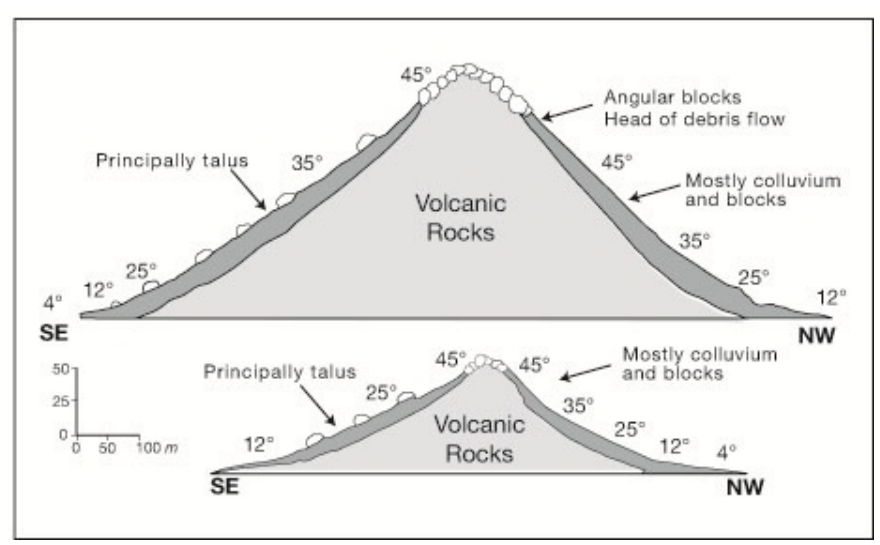

Figure 14. Two detailed profiles of small basaltic hills.

Three principal observations result from the serial cross sections of Três Forquilhas Valley. As the upper resistant acid volcanics were consumed by erosion, topographic relief within the valley was reduced, slopes became lower, and floodplains widened. In Três Forquilhas Valley the rate of valley widening downstream, calculated from the junction of Carvalho and Pinto Streams, is about one $\mathrm{km}$ per $7 \mathrm{~km}$ downstream whereas in the Maquiné valley this rate is about one kilometer per $10 \mathrm{~km}$ downstream. In both valleys width seems to increase exponentially downstream.

Davis`s 1908 model (see King \& Schumm, 1980) of slope development in a landscape underlain by alternating resistant and less resistant beds seems to apply well to the escarpment of the plateau and suggests that the resistant acid flows retreat mostly by rock falls, whereas the lower basaltic flows weather more easily and generate more colluvium. Additional colluvium and blocks are added from above by debris flows and creep so that most massive flows on lower slopes are buried by it. This process invokes parallel retreat for the upper, resistant, acid cliff-forming flows and possibly non parallel retreat for the more easily weathered basaltic flows of the lower slopes. Exceptions occur where a stream impinges against a valley wall, or where an acid flow is exceptionally closely fractured and thus never forms a cliff. We fully recognize, of course, that more superficial mapping on scales of $1: 10,000$ to $1: 2000$, such as that made by Uberti (1981) for soils or by Figueró et al. (1998) for construction, are needed to fully understand in detail all the processes acting on the slopes of the escarpment, their relative importance, and the scales on which they operate. Thus the above discussion of slope evolution should be taken as a point at departure for more detailed future studies. See King (1967, p. 158-169), Selby (1985, p. 233-238 and 576586), Bloom (2004, p. 197-204), and Nott et al. (1996) for an introduction to the vast literature of the larger question of back wearing and how slopes retreat.

When slope retreat on the escarpment occurs seems much clearer to us, however, than the process question of how it occurs. We suggest that the slope retreat of the plateau is largely episodic and mostly occurs during intense rainfall such as has been well documented in Santa Catarina (Bigarella \& Becker, 1975, p. 200-206; Hermann et al., 1993; Pellerin et al., 1997), and recently in Rio Grande do Sul (Correio do Povo, 2000, p. 17; Primeira Hora, 2001, p. 14). Intense rainfall triggers failure (Fig. 15) on both colluvial slopes and cliffs, because it adds weight to the slope or face and at the same time reduces effective stress (Hunt, 1984, p. 721-723) in near surface deposits, so that a few hours of intensive rain will create ideal conditions for closely spaced landslides and debris flows. These locally strip colluvium and soil from a slope of the escarpment and redeposit it on valley floors as thick debris flow deposits - the deposits of large isolated of boulders seen on the floodplains of the larger tributaries represent old splay deposits. This is most likely to happen when slopes are still wet from earlier rains. See Pellerin et al. (1997) for such an event in nearby Santa Catarina, Jones (1973) in the coastal mountains of the city of Rio de Janeiro, and Williams (1973) for erosion from extreme rainfall from a hurricane in the Appalachian Mountains of Virginia.

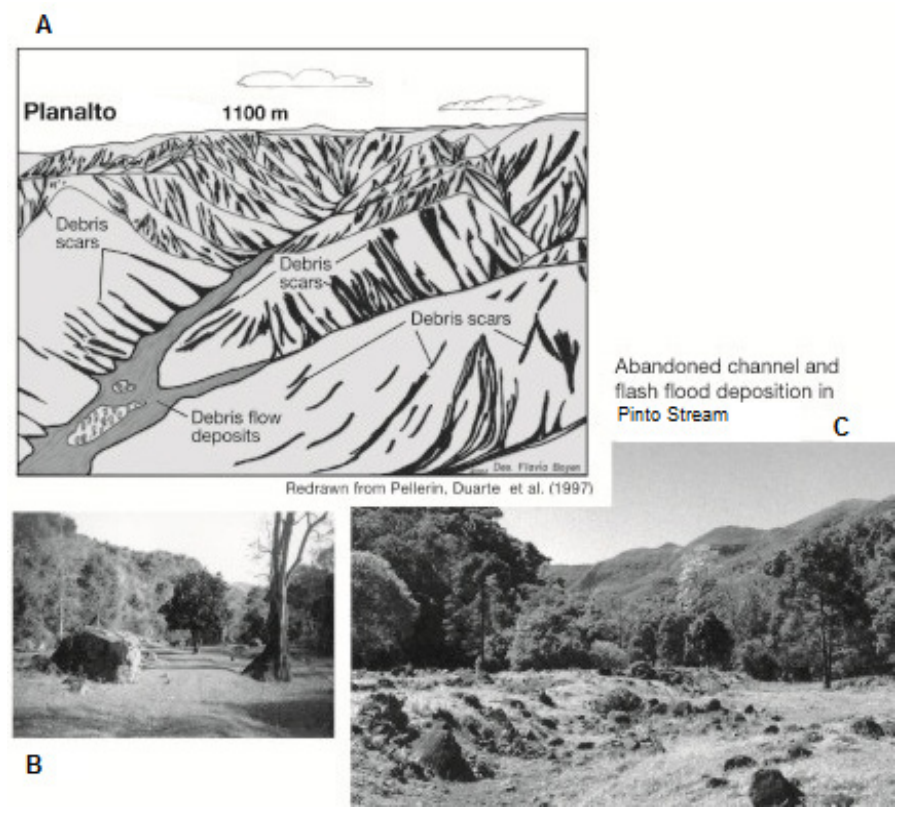

Figure 15. Debris scars and debris flows in nearby Santa Catarina State after intense rainfall (A). Abandoned channel and flash flood deposition in Pinto Stream, Três Forquilhas Basin (B and C).

\subsection{Age and origin of Três Forquilhas Valley: implications for the origin of the escarpment}

Four lines of evidence provide insights to the drainage history of Três Forquilhas and Maquiné Valleys: the far field effects of the uplift history of the Andes Mountains, the subsidence history (seismic stratigraphy evidence) of the bordering Pelotas Basin (Fig. 16), the broad regional geology of the Ponta Grossa Arch and the Rio Grande do Sul Shield, and an onshore subsurface cross section. 
The uplift of the Andes Mountains in the Middle and Late Miocene included development of high plateaus, new and reactivated thrust belts, igneous activity and major faulting plus new intermontane basins (Table 2, Chart 2). Starting at its southern end, examples of these events include the thrusted and uplifted Neuquén

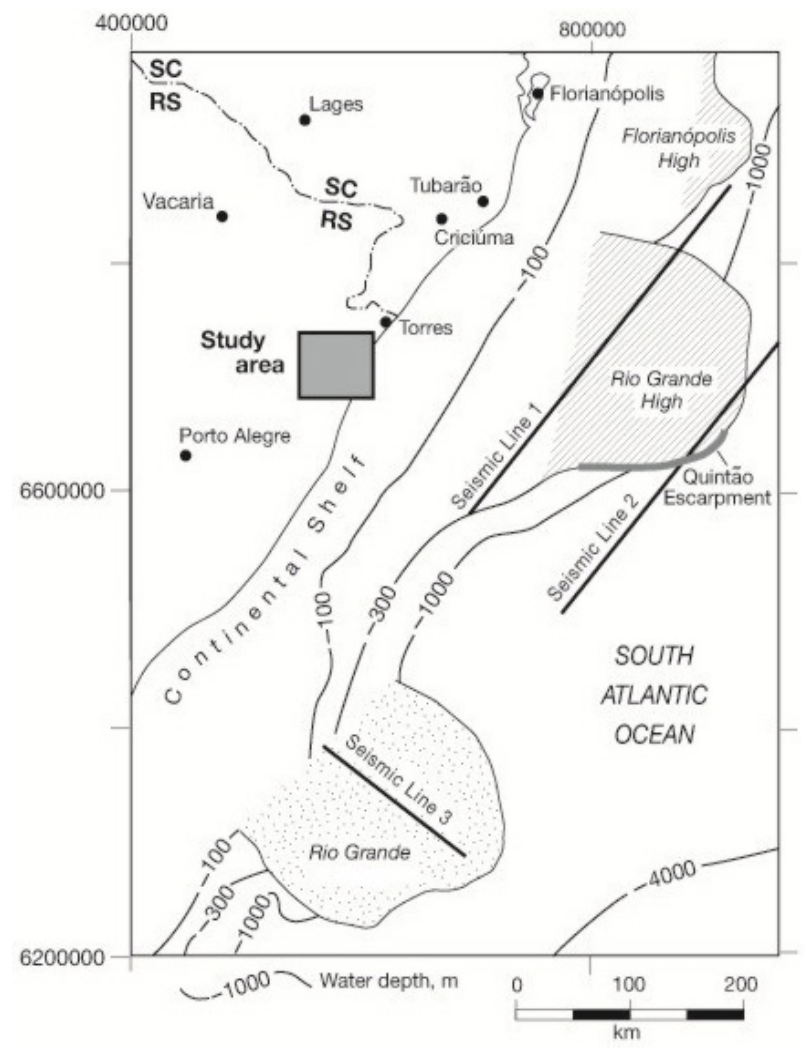

Figure 16. Location map of seismic lines in the central and northern Pelotas Basin offshore of the states of Rio Grande do Sul and southern Santa Catarina, southernmost Brazil. Note the important Rio Grande High with the Quintão Escarpment (Lines 1 and 2) on its south side and the large Rio Grande Cone 9 Line 3.
Andes in western Argentina between 37 to $39^{\circ} \mathrm{S}$ (coeval with extensive granitic intrusions) between 11to 6 Ma (Melnick et al., 2006, p. 91); the increase at 7.5 Ma of headward erosion from the Pacific in northern coastal Chile (Mortimer, 1973; Kober et al., 2006); uplift in the central Andes across the Antiplano Plateau of Bolivia was mostly between 10 and $7 \mathrm{Ma}$ in the Upper Miocene (Ghosh et al., 2006; Garzione et al., 2008, Fig. 4 ); three periods of folding occurred in the Miocene in south-central Peru, the last two at about 13 and $6 \mathrm{Ma}$ (Tosdal et al., 1984, Fig. 10); and uplift occurred in the Middle Miocene in the Merida Andes to Colombia (Parnuad et al., 1995).

Far field consequences east of the Andes include the development of the present Amazonas River near the transition between the Middle and Late Miocene (Figueiredo et al., 2009); the course change of the Orinoco from the Caribbean to the Atlantic in the late Middle Miocene (Diaz de Gomero, 1994), and the withdrawal of the Miocene seaway in Argentina and Paraguay (Sprechmann et al., 1999) as well as the abandonment of several Andean embayments (Marengo, 2000). Nearby, the thickest, 1200 -to-3800 m fill of the Chaco basin in Bolivia was deposited in the late Miocene (Uba et al., 2006, Fig. 4) and in the Llanos Basin mudstones changed from fossiliferous gray-green to non fossiliferous reddish brown near the Middle-Upper Miocene boundary (Cooper et al., 1995, p. 1435). Along much on the Brazilian coast, quartz-rich reddish brown gravels - the Barreiras Formation - were deposited both above and below the widespread Tortonian unconformity at 10.5 Ma (Arai, 2006), thus demonstrating widespread epirogenic coastal uplift far from the Andes. Such regional evidence points to probable early Middle Miocene deeping of Três Forquilhas and Maquiné Valleys with likely accelerated deepening in the Upper Miocene. See Potter \& Sztamari (2009) for other evidence of

Chart 2. Relevant South American geomorphic and paleogeographic events.

- Principal uplift of the Andes in Middle and Upper Miocene (Tosdal et al., 1984; Silva et al., 1999; Poage \& Chamberland, 2006).

- Altiplano of Bolivia uplifted between 10.3 to $6.7 \mathrm{Ma}$ as shown by carbon and oxygen isotopes of caliches in Late Miocene (Ghosh et al., 2006; Garzione et al., 2008).

- Mérida Andes rise in Middle Miocene (Parnaud et al., 1995).

- Mudstones of Llanos Basin of Columbia change from marine, greenish grey to non marine, brownish red at about 10 Ma (Cooper et al., 1995, fig. 4 and p. 1445).

- Molassic Chaco basin of Bolivia principally filled in Late Miocene.

- Amazonas River System takes present form in Late Miocene (Figueiredo et al., 2009) and the Orinoco River System in Middle Miocene (Di Croce, 1995; Diaz de Gomero, 1996, figs. 6 and 9)

- Entrerriense-Paranense seaway of parts of Paraná-Paraguay river basins abandoned in Late Miocene (Marengo, 2000; Sprechmann et al., 2001)

- Present canyons of Atacama Desert started in Late Miocene (Mortimer, 1973; Kober et al., 2006)

- Far field fracture pattern of Miocene age inferred across much of southern South America (Costa \& Hasui, 1997)

- Barreiras-type gravels of Brazil deposited as earlier Tertiary regolith is stripped from interior highlands in Middle and Late Miocene (Costa et al., 1993; Arai, 2006). 
tectonic activity in South America and globally in the Middle and Upper Miocene.

\section{Evidence from offshore seismic stratigraphy}

Sequence stratigraphy study of the three long seismic lines in the Pelotas Basin off the coast of Rio Grande do Sul (Fontana, 1990, 1996, p. 113-183; Dariva et al., 2008; Holz et al., 2008) provides a time equivalent record of the erosional history of coastal Rio Grande do Sul and southern Santa Catarina (Figs. 16 and 17). Our analysis of the offshore is based on a recently concluded research project, sponsored by Brazilian Petroleum Agency (ANP), was carried out in the Pelotas Basin to update its stratigraphy and to reevaluate its possible petroleum systems (Holz et al., 2008). Earlier published studies include the pioneer work by Fontana (1990, 1996, p. 113-183) followed by Dariva et al. (2008). Four second-order depositional sequences (1 to 4) form the infill of the Pelotas Basin (Table 3). Seismic stratigraphic analysis integrated to well log analysis permitted the uppermost Tertiary depositional sequence to be divided into seven third order sequences, labeled $4 \mathrm{~A}$ to $4 \mathrm{G}$. This shows that the sedimentation during the drift period of the basin recorded at least seven major base level falls and unconformities; i.e. sequence boundaries. The age of each depositional sequence implies a fall of base level and thus enhanced potential for erosion onshore. The age of each sequence is also the age of the unconformity at its base. Each of these unconformities represents episodes of base level fall - implying, rejuvenation of the source area followed by increased sediment influx to the adjacent Pelotas Basin. The indicated time frames of table 3 are approximations based mostly upon biostratigraphic data.

Three of the Tertiary unconformities recorded in the basin are widespread and pronounced. From this point-of-view, the story of entrenchment of the onshore valleys is punctuated by at least three episodes of important uplifts and denudation of the source area induce base-level changes; these three erosional episodes led to the generation of three third order unconformities in the Miocene of the Pelotas Basin.

The first of these important unconformities occurs between depositional sequences 4D and 4E, and has an Early Miocene age (Aquitanian, approximately $24 \mathrm{Ma}$ ), as calibrated by available biostratigraphic data. The second unconformity is between sequences 4E and F, with an age of Early Middle Miocene (Langhian, approximately $15 \mathrm{Ma}$ ), and the third relevant unconformity is between sequences $4 \mathrm{~F}$ and $4 \mathrm{G}$ which was formed during the Middle to Late Miocene, Serravalian to Tortonian at approximately $12 \mathrm{Ma}$. Bueno et al. (2007, p. 559), additionally noted, unconformities at $10 \mathrm{Ma}$ and $5 \mathrm{Ma}$, although the three lines of figure 19 do not confirm them.

Other evidence for periods of increased sediment influx is given by analysis of three seismic lines (Figs.
17 and 18). These lines were supplied by ANP and are simply identified as line 01,02 and line 03 due to confidentiality restrictions.

First, all three seismic lines show that sequences $4 \mathrm{~F}$ and $4 \mathrm{G}$ are thicker than the earlier Tertiary sequences. This implies accelerated erosion onshore and more accommodation in the basin offshore. Secondly, seismic study of seismic lines 01 and 02 (Fig. 18) revealed that in the northern part of the basin, close to the Florianópolis High (which delimits the Pelotas Basin from the adjacent Santos Basin) there is a sedimentary buildup forming a huge plateau-like structure historically known as the Rio Grande High (Fig. 17). This sedimentary feature is located seawards in front of the study area. Here sequences $4 A$ to G show a very interesting pattern regarding deposition and erosion quite possibly linked to the onshore uplift and entrenchment of the two nearby valleys during Early to Middle Miocene time,

Seismic line 01 (Fig. 18) clearly reveals the sedimentary nature of the Rio Grande High, with depositional sequences $4 \mathrm{~A}$ to $4 \mathrm{G}$ forming a thick sedimentary pile suggesting intense sediment influx at that part of the basin. The thickness of each depositional sequence is greater at their flanks than over the high (less accommodation space), showing that this structural features was controlling the sedimentation in that area since the Late Cretaceous; i.e., the bulk of sediments were deposited at the flanks of that structure.

Within this scenario, a particular feature seems to indicate times of increased sediment influx. This feature, here named the Quintão Escarpment, is a huge escarpment generated by slides or slumps at the southern margin of the Rio Grande High. Seismic line 02 crosses the Quintão Escarpment revealing two important stratigraphic relationships: first, depositional sequences $4 \mathrm{~A}$ to $\mathrm{C}$ drape its relief decreasing in thicknesses from its flank towards the capping structural high, and secondly, sequences $4 \mathrm{D}$ to $4 \mathrm{G}$ are partly deformed on the steep escarpment surface at the southern margin of the Rio Grande High. This deformation (collapse) affects mainly sequences $4 \mathrm{E}$ and $4 \mathrm{~F}$, sequence $4 \mathrm{D}$ to a lesser extent, and the basal part of sequence 4G. Hence, the epoch of onset of each of these sequences (which is a time of base level fall generating unconformities in the stratigraphical record) seems to be coincident with a very huge sediment input, which caused rapid sedimentary up building and consequent instability of the sedimentary pile, and thus the slides and slumps of the Quintão Escarpment.

Seismic line 03, about $300 \mathrm{~km}$ to the southwest of the Quintão Escarpment, crosses a large deltaic feature known as the Rio Grande Cone. This line shows both increased sediment influx during the deposition of the Mid- to Late Miocene sequences and a large system of normal, synthetic and antithetic faults plus reverse and thrust faults, caused by collapse of the delta front; this décollement affects mainly sequence $4 \mathrm{~F}$ and the base 
of sequence 4G of latest Miocene age (Chart 3).

In sum, we propose that the initiation of most of the relief of the valleys of Três Forquilhas and Maquiné is a far field response in the Middle to Late Miocene to the distant Andean orogeny, an orogeny coincident with many other events throughout South America (Chart 2). Locally, our interpretation is fully supported and amplified by the seismic stratigraphy of the Pelotas Basin. In the Pelotas Basin there are at least three third-order base level changes, which generated sequences 4E, $4 \mathrm{~F}$ and 4G. The approximate ages of the implied unconformities are 24, 15, and 12 Ma (Chart 3). All of these three sequences were affected by slumps and sli- des apparently due to overloading by rapid sediment input. The dominance of shale in the basin in these sequences is consistent with humid climate weathering of the Serra Geral volcanics that form the escarpment.

We found seven Tertiary unconformity-bound sequences in all three lines (Chart 3). Two occurs when many Andean far field events across South America were in progress - one at 15 Ma (Middle-Lower Miocene boundary) and the other at $12 \mathrm{Ma}$ (Middle Miocene); Bueno et al. (2007) reported one at the Upper-Middle boundary at $10 \mathrm{Ma}$. These unconformities result from relative sea level fall - implying rejuvenation of the source area followed by increased flux to the Pelo-

Chart 3. Geomorphic and engineering characteristics of lava flows (adapted from Figueró et al., 1990).

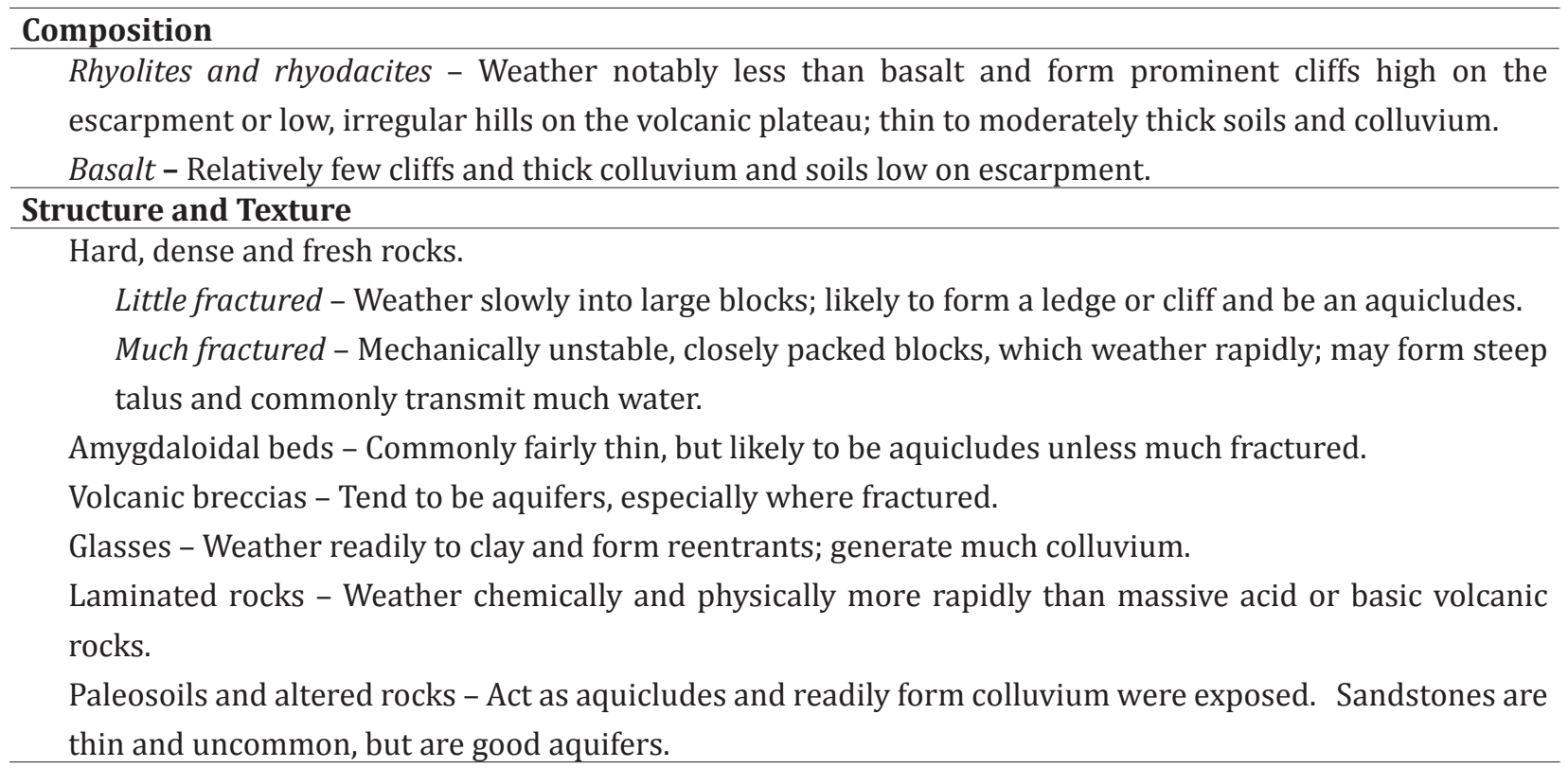

tas Basin; for example, Unit G $(12 \mathrm{Ma}<)$ is the thickest of all the Neogene units in all three seismic sections. This large relative fall in sea level, resulted in rapid sedimentation up building (decrease in accommodation) and consequent instability (overpressure) in the sedimentary pile of the Pelotas Basin. This caused slides and slumps on the Quintão Escarpment and induced collapse of the delta front of the Rio Grande Cone (whose displaced units are capped by latest Miocene beds). Thus we suggest that much of the present relief of Três Forquilhas and Maquiné Valleys was initiated in the Middle Miocene or even possibly as late as the Upper Miocene judging by Bueno et al. (2007, p. 558-559), who also identified unconformities at 10 and $5 \mathrm{Ma}$. Thus three types of offshore evidence - unconformities, enhanced thicknesses between these unconformities and slumping - point to onshore rejuvenation starting in the Middle Miocene with probable acceleration in late Miocene time (Fig. 18).

\section{Earlier evidence for paleorivers}

What can be inferred about the age of the oldest drainage in the study area? The uplift history of the Ponta Grossa Arch and the Sul-Rio-Grandense Shield plus the cross section of figure 4 provide insights to this interesting question. Remembering that the watersheds of Três Forquilhas and Maquiné Valleys occupy the lowest structural point (the Torres Syncline) between the two structural highs of the Rio Grande Shield and Ponta Grossa Arch, the age of uplift of these two regional highs gives the earliest age of ancestral drainage. Using apatite fission tract dating (Vignol-Lelarge, 1993, p. 91-93) found that initial uplift of the Ponta Grossa Arch occurred at $110 \mathrm{Ma}$ and its maximum rate was between 90 to 110 Ma (Turonian through Albian). Thus, sometime in the late Cretaceous there must have been a river system occupying the present structural low of Três Forquilhas and Maquiné Valleys that flowed into a narrow, but rapidly widening Atlantic Ocean. This im- 

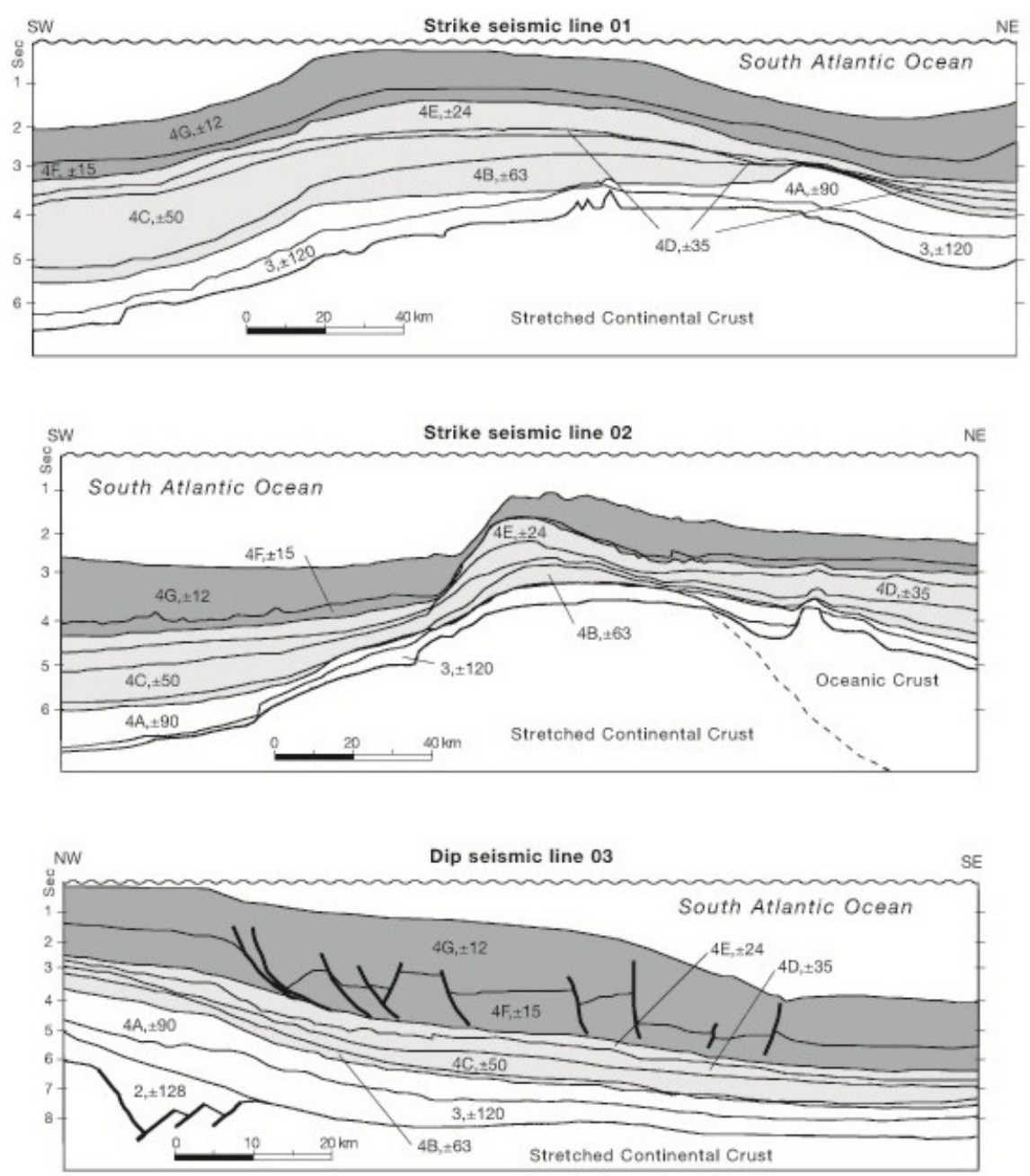

Figure 17. Offshore seismic lines: note the greater thickness of the third order sequences $4 \mathrm{G}$ and $4 \mathrm{~F}$ in all three lines, the mound structure and scarp of the Rio Grande High on Line 2, and the décollement of the Rio Grande Cone of Line 3. Faulted slices within the décollement of Line 3 have a Lower Miocene seismic signature showing that movement was post Lower Miocene.

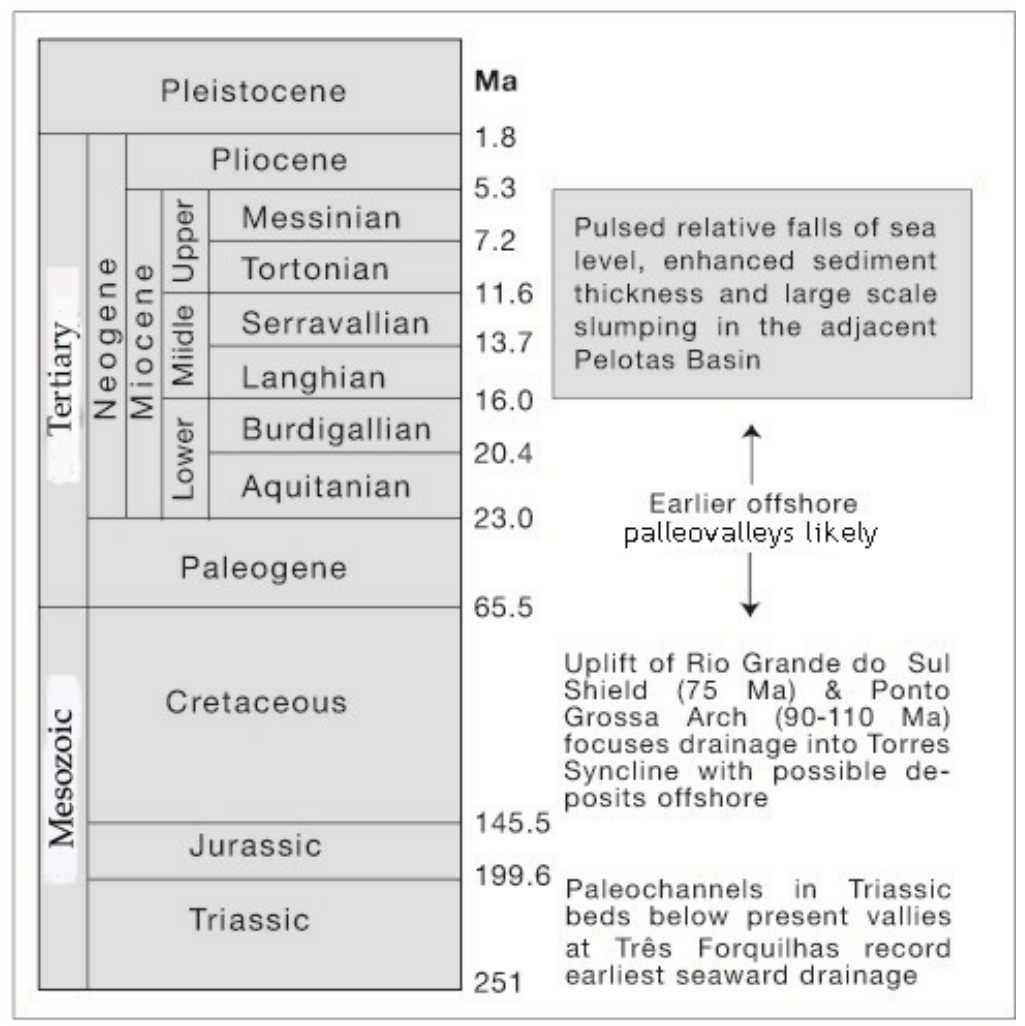

Figure 18. Summary of drainage evolution in the study area. 
plies that somewhere at sea there should be a delta, fan delta or deep sea fan supplied by sediment from this early drainage system. From studies of vitrinite reflectance along the east side of the Paraná Basin, Zanotto (1993) inferred as much as 2,500 m of erosion - so such possible deposits might be considerable.

The stratigraphic and topographic cross sections of the Torres Syncline permit us to identify even earlier paleodrainage near Terra de Areia. The stratigraphic cross sections of figure 4 show two erosional valleys, one at the base of the eolian Botucatu Formation (Jurassic-Cretaceous) and the other at the base of the lavas of the Serra Geral Formation (Triassic-Jurassic). One is above the other and both are close to the axis of the Torres Syncline. In addition - and most significantly - both are directly below the present mouths of the Três Forquilhas and Maquiné Rivers. Thus in late Triassic time, the Torres Syncline was already a topographic low focusing drainage to the sea. Consequently, we infer that the present valleys of Três Forquilhas and Maquiné Rivers had their most distant beginnings as long ago as the Late Triassic some $200 \mathrm{Ma}$ ago.

In sum, we propose that the valleys of Três Forquilhas and Maquiné Rivers both have had similar ages and origins. The beginnings of much of their present landscape came into existence in response to Andean far-field tectonics in the Middle Miocene with accelerated uplift and erosion beginning in the Late Miocene. Both rivers follow well defined south southeast trending fractures in a broad, gently, seaward-dipping syncline toward the Atlantic Ocean. The presence of two broad paleovalleys in the subsurface - one as old as Triassic - implies that the Torres Syncline was a topographic low even in the middle of the Mesozoic.

\section{Conclusions}

The initial relief of the present valleys of Três Forquilhas and Maquiné was initiated as the volcanic plateau in the region of the Torres Syncline was uplifted in the Middle Miocene in response to far field Andean orogeny; this caused accelerated erosion of the escarpment of the volcanic plateau as shown by unconformities, increased thicknesses and slumping in the nearby the offshore Miocene section. Judging by offshore seismic unconformities, later rejuvenation followed at 12 , 10 and $5 \mathrm{Ma}$.

Inferences about earlier drainage are based on dating by apatite fission track studies and a subsurface cross section:

a. Uplift of the Rio Grande de Sul Shield (74 Ma) and the Ponta Grossa Arch (90 to $100 \mathrm{Ma}$ ) in the late Cretaceous left the Torres Syncline as a structural low between two highs and focused drainage into a widening South Atlantic Ocean.

b. A subsurface cross section across the Torres Syncline shows two paleovalleys, one filled by the Triassic-Jurassic Botucatu Formation the other by lavas of the Jurassic-Cretaceous Serra Geral Formation, indicating even earlier drainage in this structural low. This paleodrainage suggests that there may be hidden deltas or subsea fans offshore.

c. The spatial coincidence of both present valleys and ancient buried valleys in the Torres Syncline demonstrates an exceptional long term, $200 \mathrm{Ma}$ tectonic control of paleotopography in this part of coastal Brazil.

Drainage, at all scales in both watersheds, is strongly controlled by a fracture pattern closely related to that of the opening of the South Atlantic Ocean.

In both valleys episodic erosion today and in the past powered headward erosion dominantly by parallel slope retreat through creep, rock fall, slope failures and debris flows.

Today, most headward erosion occurs in pulses during heavy rainfall; it thus seems probable that similar processes operated on scales from $10^{4}$ to $10^{5}$ years in the past.

Judging by the absence of knickpoints in longitudinal profiles, both valleys have equilibrium landscapes graded to present sea level and seemingly no record of earlier rejuvenations.

Acknowledgments: We appreciate the sustained support of the Institute of Geociences for field transport and the helpful commentaries of L.A. Bressani, C. Scherer, S. Dillenburg (UFRGS) R. Lopes and W. Wildner (CPRM-RS). We thank R.L. Fontana (PETROBRAS S.A.) for reading the manuscript and for his earlier studies. R. Dias introduced us to the volcanic stratigraphy of the Serra Geral Formation. Michael Holz acknowledges Agência Nacional do Petróleo (ANP-SDB) for supplying seismic lines, Conselho Nacional de Pesquisa e Desenvolvimento (CNPq) for a personal scholarship (Grant 3026666/04-4). Finally, we much appreciated the sustained support of the Instituto de Geociências, UFRGS.

\section{References}

Aboarrage, A.M. \& Lopes, R.C. 1986. Projeto Borda Leste da Bacia Paraná: Integração Geológica e Avaliação Econômica; Relatório Final. Comissão Pesquisa Recursos Minerais, São Paulo e Porto Alegre, v. 1, 15p.

Ab'Saber, A.N. 1969. Participação das superfícies aplainadas nas paisagens do Rio Grande do Sul. Geomorfologia, 11: 1-17.

Almeida, F.F.M. 1952. Contribuição a geomorfologia da região oriental de Santa Catarina. Boletim Paulista de Geografia, 10: 3-32.

Arai, M. 2006. A grande elevação eustática do Mioceno e sua influência na origem do Grupo Barreiras: Geologia USP, Série Científica, 6 (2): 1-6.

Araújo, L.M., Franca, A.B., \& Potter, P.E. 1999. Hydrogeology of the Mercosul aquifer in the Parana and Chaco-Parana Basins, South America, and comparision with the Navajo-Nuggett aquifer system USA. Hydrogeology Journal, 7: 317-336.

Bellieni, G., Comin-Chioramonti, L.S., Marques, L.S., Melfi, A.J., Nardy, A.J.R., Papatrechas, C., Piccirillo, E.M., Roisenberg, A. \& Stolfa, D. 1986. Petrogenetic aspects of acid and basaltic lavas from the Paraná Plateau (Brasil): Geological, 
mineralogical and petrochemical relationships. Journal of Petrology 27: 915-944.

Bigarella, J.J. \& Mousinho, M.R. 1966. Slope development in southeastern and southern Brazil. Zeitschrift für Geomorphologie N.F., 10: 150-160.

Bigarella, J.J. \& Becker, R.D. 1975. Catastrophic events in the Tubarão. International Simposium on the Quaternary. Boletim Paranaense de Geociências, 33: 200-206.

Bishop, P. 1988. The Eastern Highlands of Australia: the evolution of an intra-plate highland belt. Progress Physical Geography, 12: 159-182.

Bloom, A.L. 2004. Geomorphology. 3rd ed., Waveland Press, Long Grove, 492 pp.

Brown, P.G. 1971. Contribuição a geomorfologia do Brasil Central. Revista Brasileira de Geografia, 3: 3-40.

Bueno, G.V., Zacharias, A.A., Oreiro, S.G., Cupertino, J.A., Falkenhein, F.U.H. \& Martins, M.A.N. 2007. Bacia de Pelotas, In: Milani, E. J., (Coordenador), Rangel, H.A., Bueno, G.V., Stica. J.S., Winter, W.R., Caixeta, J. M., Pessoa, O.C., Bacias Sedimentares Brasileiras - Cartas Estratigráficas. Boletim de Geociências da Petrobrás, 15:551-559.

Cainelli, C. \& Mohriak, W.U. 1998. Geology of the Atlantic Eastern Brasilian Basins, Brasilian Geology . Part II. AMERICAN ASSOCIATION PETROLEUM GEOLOGISTS INTERNATIONAL CONGRESS, 1998, Rio de Janeiro, v.1, p. 8-11.

Clapperton, C. 1993. Quaternary Geology and Geomorphology of South America. Elsevier, Amsterdam, 779pp.

Coates, A.G. \& Obando, J.A. 1996. The geologic evolution of the Central American Isthmus. In: Jackson, J.B.C., Budd, A. F., Coates A.G., (Eds.) Evolution of Environment in Tropical America. University of Chicago Press, Chicago and London, p. 21-56.

Cooper, M. A, Addison, F.T., Alvarez, R., Coral, M., Graham, R.H., Hayward A. B., Howe, S., Martinez, J., Naar, J. Peñas., R., Pulhman, A.J. \& Taborda, A. 1995. Basin development and tectonic history of the Eastern Llanos Basin, Eastern Cordillera and Magdallena Valley, Columbia. American Association of Petroleum Geologists Bulletin, 79: 14211443.

Correio do Povo. 2000. Agricultores temem mais deslizamentos. Porto Alegre, 27 Dezembro 2000, p.17.

Costa, J.B.S. \& Hasui, Y. 1997. Evolução Geológica da Amazônia. In: Costa, M.L., Angélica, R.S., (Eds), Contribuição a Geologia da Amazônia. Belém, Sociedade Brasileira de Geologia - SBG/ Financiadora de Estudos e Projetos FINEP, p. 15-50.

Costa, J.B.S, Borges, M.S., Bemerguy, R.L., Fernandes, J.M.G., Costa, P.S. \& Costa, M.L. 1993. Evolução Cenozoica da região de Salinópolis, Nordeste do Estado do Pará. Geociências, 12 (2): 373-396.

CPRM. Companhia de Pesquisa de Recursos Minerais, \&d FEPAM. Fundação de Proteção Ambiental. 1998. Mapeamento Geológico Integrado de Bacia Hidrográfico do Guaíba. Serviço Geológico do Brasil and Fundação de Proteção Ambiental, Porto Alegre. Escala 1:500.000.

Dariva, P., Casagrande, J., Holz, M. \& Muricy, A. 2008. Mapeamento sismo-estratigráfico de Bacia de Pelotas. In: CONGRESSO BRASILEIRO DE GEOLOGIA, 32., 2008, Curitiba. Anais... Curitiba, SBG, CD-Rom, PDF 1345.

Departamento Nacional de Águas e Energia Elétrica - DNAEE, 1975-1996. Precipitação do município de Terra de Areia, 1975 to 1996. Unpaged.

Dias, J.L., Sad, A.R.E., Fontana, R.L. \& Feijó, F.J. 1994. Bacia de Pelotas. Boletim Geociências PETROBRAS, 8: 235-246.
Diaz de Gomero, M.L. 1994. The changing course of the Orinoco River during the Neogene: A review. Paleogeography, Paleoclimatology, Paleoecology, 123: 385-402.

Di Croce, J. 1995. Eastern Venezuela, basin: sequence stratigraphy and structural evolution. PhD. Thesis, 225 pp. Department Earth Sciences, Rice University, Houston.

Domingos, C.L. 1997. Três Forquilhas - RS: auto-retrato. Terra de Areia: Editora \& Gráfica Triângulo, 39 pp.

Figueiredo, J., Hoorn , C., van der Ven, P. \& Soares, E. 2009. Late Miocene onset of the Amazon River and deep sea fan: Evidence from the Foz do Amazonas Basin. Geology, 37: 619-622.

Figueró, J.E., Bressani, L.A. \& Maciel Filho, C.L. 1998. Mapeamento geotécnico da RS-486, Rota do Sol, no Rio Grande do Sul. In: SIMPÓSIO BRASILEIRO DE CARTOGRAFIA GEOTÉCNICA, 32., 1998, Florianópolis. Anais... Florianópolis, SBG, CD-Rom, 10 pp.

Filho, O. A. \& Virgili, J.C. 1998. Estabilidade de taludes, In: Oliveira, A.M. dos S., Brito, S.N.A., (Eds), Geologia de Engenharia. São Paulo. Associação Brasileira de Geologia e Engenharia (Abge), p.244-269.

Fontana, R.L. 1990. Investigações geofísicas preliminares sobre o Cone do Rio Grande, Bacia de Pelotas. Acta Geologica Leopoldensia, 36: 161-170.

Fontana, R.L. 1996. Geotectônica e seismoestratigrafia da Bacia de Pelotas e Plataforma de Florinópolis. Porto Alegre, 241p. Tese de Doutorado, Programa de Pós-graduação em Geociências, Instituto de Geociências, Universidade Federal do Rio Grande do Sul.

Garzione, C. N., Hoke, G. D., Libarnkin, J. C., Withers, S., MacFadden, B., Eiler, J., Gosh, P. \& Mulch, A. 2008. Rise of the Andes. Science, 320: 1304-1307.

Ghosh, P., Garzione, C.M. \& Eilor, J.M. 2006. Rapid uplift of the Altiplano revealed through ${ }^{13} \mathrm{C}-{ }^{18} \mathrm{O}$ bonds in paleosol carbonates. Science, 311: 511-515.

Gilardi da Silva, F. \& Scherer, C.M.S. 2001. Fácies, associação de fácies e modelo deposicional dos arenitos eólicos da Formação Botucatu (Cretáceo Inferior) na região Sul de Santa Catarina. Pesquisas em Geociências, 27: 15-30.

Har Engenharia. 1990. Relatório de Impacto Ambiental da rodovia $R S$ - 230/486, Rota do Sol, Trecho Tainhas-Terra de Areias. Departamento Autônomo de Estradas de Rodagem (Porto Alegre, RS), v. 1, 191pp.

Hermann, M.L.P., Mendonça, M. \& Campos, N.J. 1993. São José: avaliação das enchentes e deslizamentos ocorridos em novembro de 1991 e Fevereiro de 1994. GEOSUL, 16: 46-78.

Holz, M., Kuchie, J., Casgrande, J., Dariva, P., Rolim, S.B.A., Boingioio, D.E. \& Muricy, A. 2008. Análise multidisciplinar de bacias sedimentares - novas perspectivas exploratórias para a Bacia de Pelotas. In: CONGRESSO BRASILEIRO DE GEOLOGIA, 32., 2008, Curitiba. Anais... Curitiba, SBG, CD-Rom, PDF 0849.

Horn Filho, N.O., Loss, E.L., Tomazelli, L.J, Vilwock, J.A., Dehnhardt, E.A., Koppe, J.C. \& Godolphim, M.F. 1984a. Mapa Geológico das Folhas Maquiné e Arroio Teixeira. Universidade Federal do Rio Grande do Sul/CECO, Escala $1: 100.000$.

Horn Filho, N.O., Loss, E.L., Tomazelli, L.J., Villwock, J.A., Dehnhardt, E.A. \& Koppe, J.C. 1984b. Mapa Geológico das Folhas Três Cachoeiras e Torres. Universidade Federal do Rio Grande do Sul/CECO, Escala 1:100.000.

Howard, A.D. 1967. Drainage analysis in interpretation: a summation. American Association Petroleum Geolologists 
Bulletin 51: 2246-2259.

Hunt, R.E. 2005. Geotechnical Engineering Investigation Manual. McGraw-Hill Book Co., $2^{\text {nd }}$ ed., New York, 1066 p.

IBGE - Instituto Brasileiro de Geografia e Estatística, 1990. Geografia do Brasil, Região Sul. Instituto Brasileiro de Geografia e Estatística, 419p.

IBGE - Instituto Brasileiro de Geografia e Estatística, 1993. Mapa de Unidades do Relevo do Brasil. Secretaria de Planejamento, Orçamento e Coordenação da Presidência da República, Instituto Brasileiro de Geografia e Estatística, Escala 1:5.000.000.

Jones, F.O. 1973. Landslides of Rio de Janeiro and Serra das Araras Escarpment, Brazil. U.S. Geological Survey Professional Paper 697, 42pp.

Justus, J. O., Machado, M.L.A. \& Franco, M.S.M. 1986. 2-Geomorfologia in Radam Brasil, Folha SH.22 Porto Alegre e SH.21 Uruguaiana e SI.22 Lagoa Mirim. Levantamento de Recursos Naturais, Fundação Instituto Brasileiro de Geografia e Estatística 33: 313-387.

King, L.C. 1953. Cannons of landscape evolution. Bulletin Geological Society America, 64: 721-752.

King, L.C. 1956. A Geomorfologia do Brasil Oriental. Revista Brasileira de Geografia, 18: 147-256.

King, L.C. 1967. The Morphology of the Earth, 2nd ed. Oliver and Boyd, London, $726 \mathrm{pp}$.

King, P.B. \& Schumm, S.A. 1980. The Physical Geography (Geomorphology) of William Morris Davis. Norwich, Geo Books 217 pp.

Kober, W.S., Schulnegger, F.S., Zeilinger, G. \& Schneider, H. 2006. Surface uplift and climate change: the geomorphic evolution of the Western Escarpment of the Andes of Northern Chile between the Miocene and the present: Geological Society of America Special Paper, 398: 75-86.

Mantovani, M.S., Wilder, W. \& Juchem, J. 2000. Paraná Basin magmatism, stratigraphy, and mineralization (southern Brazil). In : INTERNATIONAL GEOLOGICAL CONGRESS, 31, Rio de Janeiro, Brazil, August 2000, Pre Congress Field Trip Bft 01, 63p.

Marengo, H.G. 2000. Rasgos micropaleontológos de los depósitos de transgresión Entrerriense-Paranense en la Cuenca Chaco-Parranense y Norodeste Argentino. In: Acenolaza F.G., Herbst, R., (Eds), El Neógene de Argentina. Universidad Nacional Tucumán/Instituto Superior Correlación Geológica (INSUGEO), Series Correlación Geológica, 14: 29-45.

Melnick, D., Rosenau, M. \& Folguera, E.H. 2006. Neogene tectonic evolution of the Neuquén Andes western flank (3739S). In: Kay, S.M., and Ramos, V.A., (Eds.), Evolution of an Andean Margin: A Tectonic and Magmatic View from the Andes to the Neuquén Basin (35-37S lat.). Geological Society of America Special Paper 407: 73-95.

Milani, E.J. \& Zalán, P.V. 2000. An outline of geology and petroleum system of the Paleozoic interior basins of South America. Episodes, 22: 99-20.

Mortimer, C. 1973. The Cenozoic history of the southern Atacama Desert. Journal Geological Society of London, 129: 505-526.

Nott, J., Young, R. \& McDougall, I. 1996. Wearing down, wearing back, gorge extension in the long-term denudation of a highland mass: quantitative evidence from the Shoalhaven Catchment, southeast Australia. Journal of Geology, 104: 224-232.

Ollier, C.D. \& Marker, M.E. 1985. The Great Escarpment of southern Africa. Zeitschrift für Geomophologie Supple- mental Band, 54: 37-56.

Ollier, C.D. \& Pain, C.F. 1994. Landscape evolution and tectonics in southeastern Australia. Journal Australian Geology Geophysics (AGSO), 15: 335-345.

Parnaud, F., Gou, Y., Pascual, J.-C., Capello, M.A., Truskowski, I. \& Passalacqua, H. 1995. Stratigraphic synthesis of western Venezuela. In: Tankard, A. J., Suárez Soruco, R., Welsink, H. J., (Eds.), Petroleum Basins of South America. American Association of Petroleum Geologists Memoir, 62: 681-698.

Partridge, T.C. \& Maud, R.R. 2000. Macro-scale evolution of Southern Africa. In: Partridge, T.C., Maud, R. R. (Eds.), The Cenozoic of Southern Africa. Oxford University Press, Oxford, p. 3-19.

Pellerin, J., Duarte, G.M., Scheibe, L.F., Mendonça, M., Buss, M.A. \& Monteiro, M.A. 1997. Timbé do Sul-Jacinto Machado: Avaliação preliminar da extensão catastrófica de 2324 /12 /1995. GEOSUL, 12: 71-86.

Poage, M.A. \& Chamberlin, C.P., 2006. Rising mountain ranges. Science, 311, 478-479.

Potter, P.E. \& Szatmari, P. 2009. Global Miocene tectonics and the modern world. Earth-Science Reviews, 96(4): 279295.

Primeira Hora, 2001. Chuva recorde em toda região. Bom Princípio, 11 Janeiro 2001, p. 14.

Ross, J.L.S. 1990. Relevo Brasileiro, uma nova proposta de classificação: Revista do Departamento Geografia da Universidade de São Paulo, 4: 25-39.

Scherer, C.M.S. 2000. Eolian dunes of the Botucatu Formation (Cretaceous) in southernmost Brazil: Morphology and origin. Sedimentary Geology, 137: 63-84.

Selby, M.J. 1985. Earth's Changing Surface. Claredon Press, Oxford. 607p.

Silva, S.R.P., Maciel, R.R. \& Severino, M.C.G. 1999. Cenozoic tectonics of the Amazon Mouth Basin. Geo-Marine Letters, 18: 256-262.

Sprechmann, P., Aceñolaza, F.C., Gaucher, C., Noriega, A.C.R. \& Perez, M.I. 1999. Transgression Paranense: Paleoestuario de Brasil del Tethys del Mioceno Medio e/o Superior en Sur America? In: XI CONGRESSO LATINOAMERICA DE GEOLOGIA Y III CONGRESSO URUGUAYO DE GEOLOGIA, XI., 2001, Montevideo. Resumenes... Montevideo. Version en CD-Room.

Tosdal, R.H., Clark, A.H. \& Farrar, E. 1984. Cenozoic polyphase landscape and tectonic evolution of the Cordilllera Occidental, southernmost Peru: Geological Society of America Bulletin, 95: 1319-1332.

Uba, C.E., Heubeck, C. \& Hulka, C. 2006. Evolution of the late Cenozoic foreland Chaco Basin, southern Bolivia. Basin Research, 18: 157-186.

Uberti, A.A.A. 1981. Características, distribuição e aptidão de uso dos solos da encosta inferior do nordeste do Rio Grande do Sul. Porto Alegre, 92p. Tese de Doutorado, Programa de Pós-Graduação em Agronomia, Instituto de Agronomia, Universidade Federal do Rio Grande do Sul.

Vandenberge, N. \& Hardenbol, J. 1998. Introduction to the Neogene. In: Charles de Graciansky, P., Hardenbol, Jan, Jacquin, T., Vail, P.R., (Eds). Mesozoic and Cenozoic Sequence Stratigraphy of European Basins. SEPM Special Publication, 60: 83-85.

Verdum, R. 2009. A Paisagem de Maquiné. In: Dilton de Castro. (Org.). História Natural e Cultural de Maquiné. Via Sapiens, 1: 31-42, 1ํㅡ ed. Porto Alegre.

Vignol-Lelarge, M.L.M., 1993. Thermochronologie par la mé- 
thode des traces de fission d'une marge passive (Dome de Ponta Grosssa, SE Bresil) et au sein d'chaine de collision (zone externe de L'Arc Alpin, France). Grenoble, 292p. Laboratoire Géophysique Nucléaire, Institut Dolomieu, Université Grenoble.

Villwock, J.A. \& Tomazelli, L.J. 1995. Geologia costeira do Rio Grande do Sul. Porto Alegre, 45p. Notas Técnicas 8, Instituto de Geociências, Universidade Federal de Rio Grande do Sul.

Weissheimer de Borba, A., Vignol-Lelarge, A.M. \& Mizusaki, A.M.P. 2002. Uplift and denudation of the Caçapava do Sul Granitoids (Southern Brasil) during the Late Paleozoic and Mesozoic: Constraints from apatite fission-track data. Journal of South American Earth Sciences 15: 683-

Manuscrito 480.

Editores: Edinei Koester e Paulo A. Souza.
692.

Widdowson, M. 1997. Tertiary paleosurfaces of the SW Deccan, Western India: implications for passive margin uplift. In: Widdowson, M, (Ed.), Paleosurfaces: Recognition, Reconstruction and Paleoenvironmental Interpretation. Geological Society Special Publication, 120: 221-248.

Williams, G.P. 1973. Erosional and depositional aspects of Hurricane Camille in Virginia. U.S. Geological Survey Professional Paper, v. 804, 80p.

Zanotto, O.A. 1993. Erosão pós-Cretáceo na Bacia do Paraná com base em dados de refletância de vitrinita. In: SIMPÓSIO SUL BRASILEIRO DE GEOLOGIA, 5., 1993, Curitiba. Anais... Curitiba, SBG, CD-Rom, p. 58. 